\title{
Ice nucleation efficiency of clay minerals in the immersion mode
}

\author{
V. Pinti ${ }^{1}$, C. Marcolli ${ }^{1}$, B. Zobrist ${ }^{1}$, C. R. Hoyle ${ }^{1, *}$, and T. Peter ${ }^{1}$ \\ ${ }^{1}$ Institute for Atmospheric and Climate Science, ETH Zurich, Zurich, Switzerland \\ *now at: Laboratory of Atmospheric Chemistry, Paul Scherrer Institut, Villigen, Switzerland \\ Correspondence to: V. Pinti (valeria.pinti@env.ethz.ch)
}

Received: 18 January 2012 - Published in Atmos. Chem. Phys. Discuss.: 30 January 2012

Revised: 11 June 2012 - Accepted: 13 June 2012 - Published: 10 July 2012

\begin{abstract}
Emulsion and bulk freezing experiments were performed to investigate immersion ice nucleation on clay minerals in pure water, using various kaolinites, montmorillonites, illites as well as natural dust from the Hoggar Mountains in the Saharan region. Differential scanning calorimeter measurements were performed on three different kaolinites (KGa-1b, KGa-2 and K-SA), two illites (Illite NX and Illite SE) and four natural and acid-treated montmorillonites (SWy-2, STx-1b, KSF and K-10). The emulsion experiments provide information on the average freezing behaviour characterized by the average nucleation sites. These experiments revealed one to sometimes two distinct heterogeneous freezing peaks, which suggest the presence of a low number of qualitatively distinct average nucleation site classes. We refer to the peak at the lowest temperature as "standard peak" and to the one occurring in only some clay mineral types at higher temperatures as "special peak". Conversely, freezing in bulk samples is not initiated by the average nucleation sites, but by a very low number of "best sites". The kaolinites and montmorillonites showed quite narrow standard peaks with onset temperatures $238 \mathrm{~K}<T_{\mathrm{on}}^{\text {std }}<242 \mathrm{~K}$ and best sites with averaged median freezing temperature $T_{\text {med }}^{\text {best }}=257 \mathrm{~K}$, but only some featuring a special peak (i.e. KSF, K-10, KSA and SWy-2) with freezing onsets in the range 240-248 K. The illites showed broad standard peaks with freezing onsets at $244 \mathrm{~K}<T_{\mathrm{on}}^{\text {std }}<246 \mathrm{~K}$ and best sites with averaged median freezing temperature $T_{\text {med }}^{\text {best }}=262 \mathrm{~K}$. The large difference between freezing temperatures of standard and best sites shows that characterizing ice nucleation efficiencies of dust particles on the basis of freezing onset temperatures from bulk experiments, as has been done in some atmospheric studies, is not appropriate. Our investigations demonstrate that immersion freezing temperatures of clay minerals strongly depend on the amount of clay mineral present per droplet and
\end{abstract}

on the exact type (location of collection and pre-treatment) of the clay mineral. We suggest that apparently contradictory results obtained by different groups with different setups are indeed in good agreement when only clay minerals of the same type and amount per droplet are compared. The natural sample from the Hoggar Mountains, a region whose dusts have been shown to be composed mainly of illite, showed very similar freezing characteristics (standard and best) to the illites. Relating the concentration of best IN to the dust concentration in the atmosphere suggested that the best IN in the Hoggar sample would be common enough downwind of their source region to account for ambient IN number densities in the temperature range of $250-260 \mathrm{~K}$ at least during dust events.

\section{Introduction}

Cloud glaciation in the atmosphere either happens via homogeneous or heterogeneous ice nucleation. While the former typically occurs at temperatures below $\sim 238 \mathrm{~K}$, the latter may take place in the whole temperature range between ice melting at $273 \mathrm{~K}$ and the onset of homogeneous ice nucleation (DeMott et al., 1997). Heterogeneous ice nucleation can proceed through different mechanisms: contact freezing (when an ice nucleus initiates freezing by contacting a supercooled droplet), condensation freezing (when ice formation occurs during water condensation on a supercooled droplet), deposition freezing (when an ice embryo forms directly by water vapour condensation on a surface) and immersion freezing (when freezing of a water droplet occurs on a foreign particle immersed in it). Various insoluble particles such as mineral dust, soot, metallic particles, volcanic ash, or primary biological particles may act as ice nuclei (IN) 
with relevance for ice cloud formation (Pruppacher and Klett, 1997; Szyrmer and Zawadzki, 1997; Hoose et al., 2010; DeMott et al., 2010). Among these IN, mineral dusts plays a predominant role (DeMott et al., 2010).

Desert dust aerosols strongly influence the Earth's radiative budget and climate either by direct interaction with solar radiation (Haywood et al., 2003) or by acting as IN and thus modifying the optical properties of clouds and their lifetime (indirect effect) (e.g. Levin et al., 1996; Rosenfeld et al., 2001; Yin et al., 2002; Rudich et al., 2002, 2003; Sassen et al., 2003; Toon, 2003; Mahowald and Kiehl, 2003).

Up to $2150 \mathrm{Mt}$ of dust from deserts are injected into the atmosphere every year (IPCC, 2007). Strong convection over desert areas may lift these aerosols into the middle and upper troposphere (Kim et al., 2004), where they can be transported over long distances (Glaccum and Prospero, 1980; Wiacek and Peter, 2009). A previous study by Wiacek et al. (2010), which examined forward air parcel trajectories initialised over desert dust areas, showed that a significant fraction (10-20\%) of the studied trajectories reached temperature and humidity regimes susceptible to mixed-phase cloud formation, indicating that freezing in the immersion mode on mineral dust from these areas could be the most relevant ice formation process.

Residuals of ice crystals that formed at $T>238 \mathrm{~K}$ are often enriched in mineral dust (Kumai, 1961; Kumai and Francis, 1962; DeMott et al., 2003a; Twohy and Poellot, 2005; Kamphus et al., 2010). Some polarization lidar measurements offer evidence of desert dust causing the glaciation of supercooled water clouds (e.g. Sassen, 2002; DeMott et al., 2003b; Sakai et al., 2004; Seifert et al., 2010). However, there seems to be variability in the IN activity, possibly related to the history and chemical aging of the dust: Seifert et al. (2010) report that in central Europe for cloud top temperatures from -10 to $-20^{\circ} \mathrm{C}$ an increased amount of ice-containing clouds (25-30\% more) was observed in air masses that contained Saharan dust compared to air masses that were advected from dust-free regions. This contrasts with lidar studies at Cape Verde (Ansmann et al., 2009) and in southern Morocco (Ansmann et al., 2008), where cloud top temperatures below $-20^{\circ} \mathrm{C}$ had to be reached before ice production could be detected.

Desert dust aerosols are mainly composed of varying shares of illite, kaolinite and montmorillonite (Kumai, 1961; Kumai and Francis, 1962; O'Hara et al., 2006; Zimmermann et al., 2008; Chudnovsky et al., 2009) depending on the source region (Avila et al., 1997; Ganor, 1991; Blanco et al., 2003; Moreno et al., 2006). These clay minerals have frequently been used as mineral dust surrogates in ice freezing experiments and their ability to act as IN is well established. However, there are large discrepancies between the observed freezing ranges: while older studies report freezing onsets as high as $-12{ }^{\circ} \mathrm{C}$ (Pitter and Pruppacher, 1973) and $-13.5^{\circ} \mathrm{C}$ (Hoffer, 1961) for droplets loaded with clay mineral particles, more recent studies detected ice nucleation on clay particles only at much lower temperatures: e.g. Lüönd et al. (2010) report the onset of droplet freezing at $-30^{\circ} \mathrm{C}$ and median freezing temperatures between $-33^{\circ}$ and $-35^{\circ} \mathrm{C}$ for droplets containing a kaolinite particle; Murray et al. (2010, 2011) measured freezing temperatures from -37 to $-27^{\circ} \mathrm{C}$ for droplets of kaolinite and montmorillonite suspensions. Therefore, these recent measurements are not able to explain the enhanced glaciation of clouds with cloud top temperatures from -10 to $-20^{\circ} \mathrm{C}$ in air masses that contained mineral dust (Seifert et al., 2010). Similar discrepancies have also been found for deposition mode ice nucleation: deposition ice nucleation experiments on different natural and surrogate mineral dusts (Salam et al., 2006; Knopf and Koop, 2006; Eastwood et al., 2008) indeed suggest a large variety of results depending on the size of the particles (Archuleta et al., 2005; Kanji et al., 2008; Kanji and Abbatt, 2010), and on the mineral and/or elemental composition (Möhler et al., 2006; Koehler et al., 2010; Kulkarni and Dobbie, 2010).

In this study, we aim at resolving some of these discrepancies by relating IN freezing temperatures to the mass concentration of the clay minerals in suspension and the droplet size. We investigate immersion freezing of kaolinites, montmorillonites and illites from different source regions and distributors. For comparison, we also investigate a natural mineral dust sample from the Sahara region (Hoggar Mountains).

Using a differential scanning calorimeter (DSC) we can perform experiments on emulsified and bulk suspensions. In the emulsion experiments a high number of micrometer-sized droplets of mineral dust suspensions are emulsified in an oil matrix. Each of the aqueous droplets contains between none and several dust particles, depending on the suspension concentration. The droplets in the emulsion freeze practically independently. Therefore, this type of experiment is sensitive to the freezing caused by average dust particles. In contrast, bulk experiments of suspensions in a similar concentration range monitor the freezing caused by the best IN, since one nucleation event causes the freezing of the whole sample. The combination of these two types of experiments and variation of the suspended mineral concentration allow for the investigation of a wide spectrum of freezing caused by a specific type of IN.

\section{Experimental setup}

Immersion mode freezing experiments using bulk and emulsion samples were performed with the Differential Scanning Calorimeter (DSC) Q10 from TA Instruments. The freezing of droplets within the emulsion or of the bulk sample is detected by means of the associated latent heat release. The DSC temperature calibration was performed with water, adamantane, cyclohexane, ammonium sulfate and indium (Zobrist et al., 2008).

The emulsions consist of 80 weight percent (wt\%) of a mixture of mineral oil (95 wt\%, Aldrich Chemical) and 
lanolin (5 wt $\%$, Fluka Chemical) and $20 \mathrm{wt} \%$ of a suspension of the IN and distilled and deionised water $(18.2 \mathrm{M} \Omega \mathrm{cm})$. The samples were emulsified by using a rotor-stator homogeniser (Polytron PT 1300D with a PT-DA 1307/2EC dispersing aggregate) for $40 \mathrm{~s}$ at $7000 \mathrm{RPM}$. We performed test experiments (see Sect. 4.2) in order to verify that the surfactant does not affect the ice nucleation efficiency of the particles.

Following the method developed by Marcolli et al. (2007), each experiment comprised three subsequent cycles starting from $20^{\circ} \mathrm{C}$ : the first and the last cycle with a cooling rate of $10 \mathrm{~K} \mathrm{~min}^{-1}$ (used as control for the emulsion stability) and the second cycle with a cooling rate of $1 \mathrm{~K} \mathrm{~min}^{-1}$ (used for evaluation). In each experiment the pure water melting point was measured during the heating part of the cycle at $1 \mathrm{~K} \mathrm{~min}^{-1}$ heating rate, to check whether the melting point was affected by species that might have dissolved from the dust particles during sample preparation. Ice nucleation temperatures of emulsion samples are derived from onsets of latent heat release peaks using the implemented software of the instrument (TA Universal Analysis) as further explained by Zobrist et al. (2006) (i.e. as the intersection of the tangent drawn at the point of greatest slope with the extrapolated baseline). Onsets instead of peak maxima were chosen because peak maxima are influenced by heat flow limitations which depend on cooling rate and absolute heat flows. The effect of heat flow limitations is illustrated in Fig. 3 of Marcolli et al. (2007) for homogenous ice freezing in an emulsion sample. All heat flux curves were normalized by the amount of suspension present in the pan, allowing a comparison of peak areas between different experiments and, thus, of the relative fractions of freezing droplet volumes.

Evaluation of freezing onset temperatures of different emulsions prepared from the same suspension showed typical standard deviations of $0.5 \mathrm{~K}$ and maximum standard deviations of $0.8 \mathrm{~K}$. These values characterize the reproducibility of the emulsification process and limit the precision of our DSC measurements.

Photographic images of emulsions prepared with aqueous suspensions of different clay minerals covering the full range of mineral concentrations used in this study were taken with an optical microscope (Olympus BX-40) in order to measure the size distribution of the droplets (Fig. 1). Droplet diameters were counted in approximately 40 images with the ImageTool program and the resulting size distribution of the emulsion was fitted with a lognormal distribution, yielding a mode diameter of $1.9 \mu \mathrm{m}$ and a geometric standard deviation of 1.8. There was no apparent dependence of droplet size distribution on clay mineral type or concentration. In each DSC experiment, $3-13 \mathrm{mg}$ of the emulsions was transferred into the pans. Emulsion samples therefore contain approximately $4 \times 10^{4}-3 \times 10^{8}$ immersed water droplets.

Bulk freezing experiments were performed using polychlorotrifluoroethylene (PCTFE) coated sample pans, into which a few milligrams (ca. $2.5 \mathrm{mg}$ ) of the suspension con-
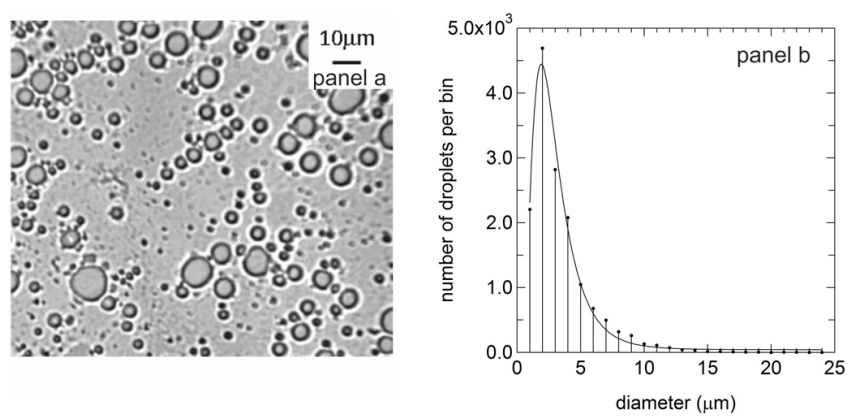

Fig. 1. (a) Optical microscope image of a typical emulsion. (b) Size distribution of the emulsion.

taining the dust was placed. Experiments with aluminium pans were also carried out. The freezing temperature is given by the abrupt onset of heat release which occurs when the whole droplet freezes instantaneously.

Particle diameters of the clay minerals were measured using a fluidized bed aerosol generator (TSI 3400A) and a scanning mobility particle sizer (SMPS) as described by Lüönd et al. (2010). The particle size distributions are given in Table 1 as mode diameters and geometrical standard deviations of lognormal distributions which were fitted to the data. Because of the small sample size, the size distribution of the Hoggar sample (see Fig. 2) was determined by evaluating electron microscope images (Philips CM12 electron microscope, ImageJ software for sizing and counting of particles).

BET (Brunauer, Emmett and Teller gas adsorption technique; Gregg and Sing, 1982) surface areas listed in Table 1 are mostly taken from literature. For illite SE no literature value was available, therefore we used the one of illite NX. The value for the Hoggar sample is from this study.

\section{Clays and dust samples}

Three different types of clay minerals were investigated in this work: kaolinite, illite and montmorillonite. Additionally a natural mineral dust sample collected in the Hoggar Mountains (Sahara) was investigated. In contrast to many other natural samples, the Hoggar Mountain dust is suited for emulsion experiments without prior artificial treatment besides sieving, because it contains a large percentage of very small particles. A summary of the studied clays and their main characteristics are shown in Table 1.

\subsection{Kaolinite}

This is a clay mineral represented by the chemical formula $\mathrm{Al}_{2} \mathrm{Si}_{2} \mathrm{O}_{5}(\mathrm{OH})_{4}$. It belongs to the phyllosilicate group. It is a layered silicate mineral, which has one tetrahedral sheet linked through oxygen atoms to one octahedral sheet of alumina octahedrals (a so called TO structure; see, for example http://webmineral.com/data/Kaolinite.shtml). This clay 
Table 1. Samples examined in this study. Exchangeable cations are given in brackets where relevant. Measured SMPS size distributions were fitted by lognormal size distributions.

\begin{tabular}{|c|c|c|c|c|c|}
\hline \multirow[t]{2}{*}{ Name } & \multirow[t]{2}{*}{ Mineral } & \multirow[t]{2}{*}{ Characteristics } & \multicolumn{2}{|c|}{$\begin{array}{l}\text { Lognormal distribution } \\
\text { fitting parameters }\end{array}$} & \multirow[t]{2}{*}{ Surface area $\left(\mathrm{m}^{2} \mathrm{~g}^{-1}\right)$} \\
\hline & & & $\begin{array}{l}\text { Mode } \\
\text { diameter } \\
d_{\mathrm{m}}(\mathrm{nm})\end{array}$ & $\begin{array}{l}\text { Geometric } \\
\text { Standard } \\
\text { deviation } \sigma\end{array}$ & \\
\hline KGa-2 & kaolinite & $\begin{array}{l}\text { high defect } \\
\text { less than } \\
7 \% \text { impurities }\end{array}$ & 360.8 & 1.8 & $\begin{array}{l}23.50 \pm 0.06 \\
\text { (Clay Mineral Society) }\end{array}$ \\
\hline $\mathrm{KGa}-1 \mathrm{~b}$ & kaolinite & $\begin{array}{l}\text { low defect } \\
\text { less than } \\
7 \% \text { impurities }\end{array}$ & 299.1 & 1.8 & $\begin{array}{l}11.8 \pm 0.8 \\
\text { (Murray et al., 2011) }\end{array}$ \\
\hline $\mathrm{K}-\mathrm{SA}$ & kaolinite & - & 446.8 & 2.0 & $\begin{array}{l}17.44 \\
\text { (Jiang et al., 2010) }\end{array}$ \\
\hline Ill SE & illite & $\begin{array}{l}\text { illite } 77 \mathrm{wt} \% \\
\text { kaolinite } 10 \mathrm{wt} \% \\
\text { calcite } 12 \mathrm{wt} \% \\
\text { quartz and } \\
\text { feldspar traces. }\end{array}$ & 327.8 & 1.9 & $104.2 \pm 0.7^{\mathrm{a}}$ \\
\hline Ill NX & illite & $\begin{array}{l}\text { illite } 86 \mathrm{wt} \% \\
\text { kaolinite } 10 \mathrm{wt} \% \\
\text { calcite } 4 \mathrm{wt} \% \text {; } \\
\text { quartz and } \\
\text { feldspar traces. }\end{array}$ & 370.7 & 1.9 & $\begin{array}{l}104.2 \pm 0.7 \\
\text { (Broadley et al., 2012) }\end{array}$ \\
\hline M STX-1b & montmorillonite & $\begin{array}{l}\text { collected in Texas } \\
\left(\mathrm{Ca}^{2+}\right)\end{array}$ & 301.4 & 2.1 & $\begin{array}{l}83.79 \pm 0.22 \\
\text { (Clay Mineral Society) }\end{array}$ \\
\hline M SWy-2 & montmorillonite & $\begin{array}{l}\text { collected in } \\
\text { Wyoming }\left(\mathrm{Na}^{+}\right)\end{array}$ & 288.2 & 2.0 & $\begin{array}{l}31.82 \pm 0.22 \\
\text { (Clay Mineral Society) }\end{array}$ \\
\hline M K-10 & montmorillonite & $\begin{array}{l}\text { treated with } \mathrm{HCl} \text {, } \\
\text { aluminosilicate } \\
\text { sheets partially } \\
\text { disrupted. }\end{array}$ & 412.0 & 1.9 & $\begin{array}{l}245 \pm 25 \\
\left(\text { Sigma-Aldrich }^{\circledR}\right)\end{array}$ \\
\hline M KSF & montmorillonite & $\begin{array}{l}\text { treated } \\
\text { with } \mathrm{H}_{2} \mathrm{SO}_{4} \text {, } \\
\text { completely } \\
\text { delaminated }\end{array}$ & 438.7 & 1.8 & $\begin{array}{l}30 \pm 10 \\
\left(\text { Sigma-Aldrich }^{\circledR}\right)\end{array}$ \\
\hline Hoggar & Saharan dust & natural & $\begin{array}{l}35^{b} \\
340 \\
2100\end{array}$ & $\begin{array}{l}1.1 \\
1.1 \\
1.4\end{array}$ & $\begin{array}{l}46.3^{\mathrm{c}} \\
\text { (this study) }\end{array}$ \\
\hline
\end{tabular}

\footnotetext{
a Illite SE BET surface area is assumed identical to BET surface area of illite NX, because no more specific literature data was available

${ }^{\mathrm{b}}$ Hoggar tri-modal size distribution.

${ }^{c}$ The BET surface was measured by $\mathrm{N}_{2}$-absorption.
}

mineral has a low cations exchange capacity in comparison to other clay minerals, such as montmorillonite (Carroll, 1959). Three types of this clay mineral were investigated, each of them having different characteristics (see Table 1). KGa-2 (Clay Mineral Society) is a high-defect kaolinite; this means that the clay mineral presents a less crystallized structure.
$\mathrm{KGa}-1 \mathrm{~b}$ is also provided from the Clay Mineral Society and it is classified as a low-defect kaolinite, i.e. a clay mineral that presents a well crystallized structure. K-SA is available from Sigma Aldrich; this company does not provide any further information about the clay (collection place, pre-treatments, etc.). Nevertheless, since its ice nucleation properties have 


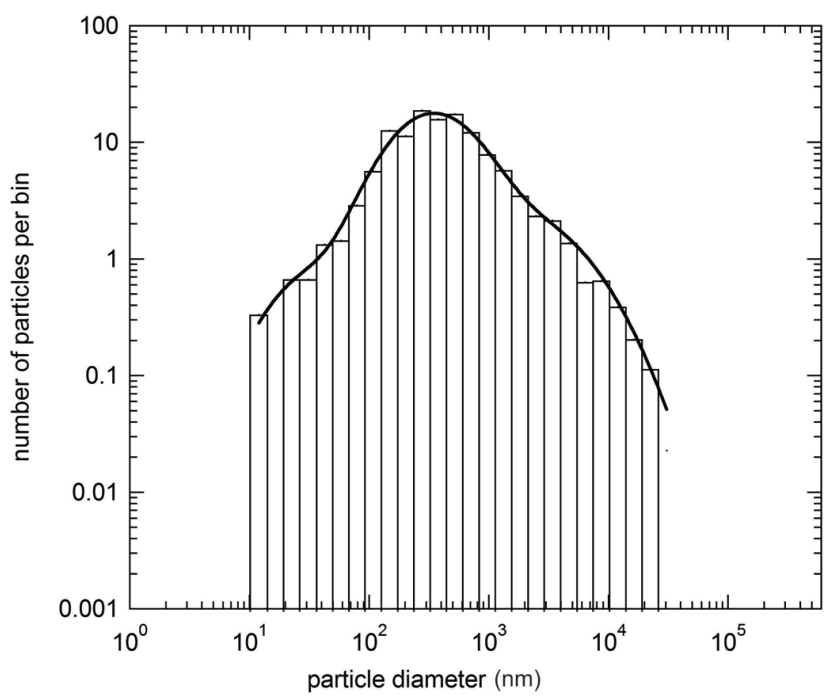

Fig. 2. Tri-modal lognormal distribution: best fit to the Hoggar sample size bins.

been investigated in many previous studies (Eastwood et al., 2008; Lüönd et al., 2010; Welti et al., 2009), a further study of K-SA is useful for comparison with literature data.

\subsection{Illite}

It belongs to the phyllosilicate and the mica groups and tends to be an agglomerate of numerous individual crystals or clusters. Its structure is given by the repetition of an octahedral layer sandwiched between two tetrahedral layers (TOT) (Viani et al., 2002). "The interlayer space is mainly occupied by poorly hydrated potassium cations responsible for the absence of swelling" (Kumar et al., 2011). The chemical formula is given as $\left(\mathrm{K}, \mathrm{H}_{3} \mathrm{O}\right)(\mathrm{Al}, \mathrm{Mg}, \mathrm{Fe})_{2}(\mathrm{Si}, \mathrm{Al})_{4} \mathrm{O}_{10}\left[(\mathrm{OH})_{2},\left(\mathrm{H}_{2} \mathrm{O}\right)\right]$ (Arginotec) and it has a higher cations exchange capacity than kaolinite, but still less than montmorillonite (Carroll, 1959). Due to its small grain size and defective character, the crystal structure of illite is poorly known (Nieto et al., 2010). Two different types of illite from Arginotec were used: Ill NX and Ill SE. These two samples mainly differ in their mineral composition, since they are not entirely composed of illite (see Table 1). Mineral composition of Ill NX is given by the company technical sheet, although in a recent study (Broadley et al., 2012) X-ray measurements showed slight differences in mineral composition of Ill NX: $74.3 \%$ of illite and illitesmectite mixed layers, $6.6 \%$ of quartz, $9.8 \%$ of feldspar, $2.1 \%$ of carbonate and $7.2 \%$ of kaolinite.

\subsection{Montmorillonite}

It belongs to the phyllosilicate group and is a member of the smectite family. Like illite it presents a TOT structure and its chemical formula is given by
$(\mathrm{Na}, \mathrm{Ca})_{0.33}(\mathrm{Al}, \mathrm{Mg})_{2}\left(\mathrm{Si}_{4} \mathrm{O}_{10}\right)(\mathrm{OH})_{2} \cdot n \mathrm{H}_{2} \mathrm{O}$. Montmorillonite has a high cation exchange capacity (Carroll, 1959). Four kinds of Montmorillonite were investigated in this study. M STx-1b and M SWy-2 were both provided by the Clay Mineral Society. While M STx-1b presents interlayer $\mathrm{Ca}^{2+}$ cations, M SWy-2 has $\mathrm{Na}^{+}$interlayer cations. Acid activated montmorillonite is widely used as catalyst (http://www. sud-chemie.com/) and can be purchased, e.g. from Sigma Aldrich. M K-10 has been treated with $\mathrm{HCl}$ such that its aluminosilicate sheets are partially disrupted (Ajjou et al., 1997). Such a strong acid treatment surely does not represent atmospheric conditions, however, since this montmorillonite sample has been often used in ice nucleation experiments (Welti et al., 2009; Eastwood et al., 2008; Salam et al., 2006; Kanji et al., 2008), we investigate it for comparison.

M KSF (Sigma Aldrich) is a montmorillonite that was chemically treated with $\mathrm{H}_{2} \mathrm{SO}_{4}$ and therefore the crystal structure is completely delaminated (personal communication from Sigma Aldrich), which means that the typical layered TOT structure of this clay is broken up. A melting point depression to $272.4 \mathrm{~K}$ was detected for a $10 \mathrm{wt} \%$ suspension of this clay mineral, which would correspond to ca. $2.5 \mathrm{wt} \%$ sulphuric acid in solution assuming a pure $\mathrm{H}_{2} \mathrm{SO}_{4}$ solution. The acidity of the suspension/solution was also confirmed by measuring its $\mathrm{pH}$ using litmus paper. The melting point depression starts to be detectable for a $2 \mathrm{wt} \%$ suspension of $\mathrm{M}$ KSF (272.9 K).

\subsection{Hoggar mountain dust}

Sources of Saharan dust emissions have been found to be mostly located in the centre of North Africa (Schulz et al., 1998). The Hoggar (or Ahaggar) mountains are situated in southern Algeria as part of an area, which has been identified as major source of desert dust aerosol (Laurent et al., 2010). The Hoggar sample was kindly provided by L. Schütz (Johannes Gutenberg-Universitaet, Mainz). Previous studies of a sample from a similar location show that in this region the clay fraction of the mineral dust is mainly composed of illite $(87 \%)$, followed by kaolinite $(11 \%)$ and montmorillonite (2\%) (Ganor, 1991); Moreno et al. (2006) reported that their sample also contained $19 \%$ of quartz and diatomaceous hydrated amorphous silica. Our sample showed rapid sedimentation when put in suspension, therefore we sieved it ( $32 \mu \mathrm{m}$ grid) to remove the coarse particles. The size distribution of the dust was investigated after sieving giving a tri-modal lognormal size distribution (see Table 1 and Fig. 2) as best fit. This sample, differently from the clay samples, shows a reddish colour, indicating that iron oxide could be present (Lancaster, 1995). 

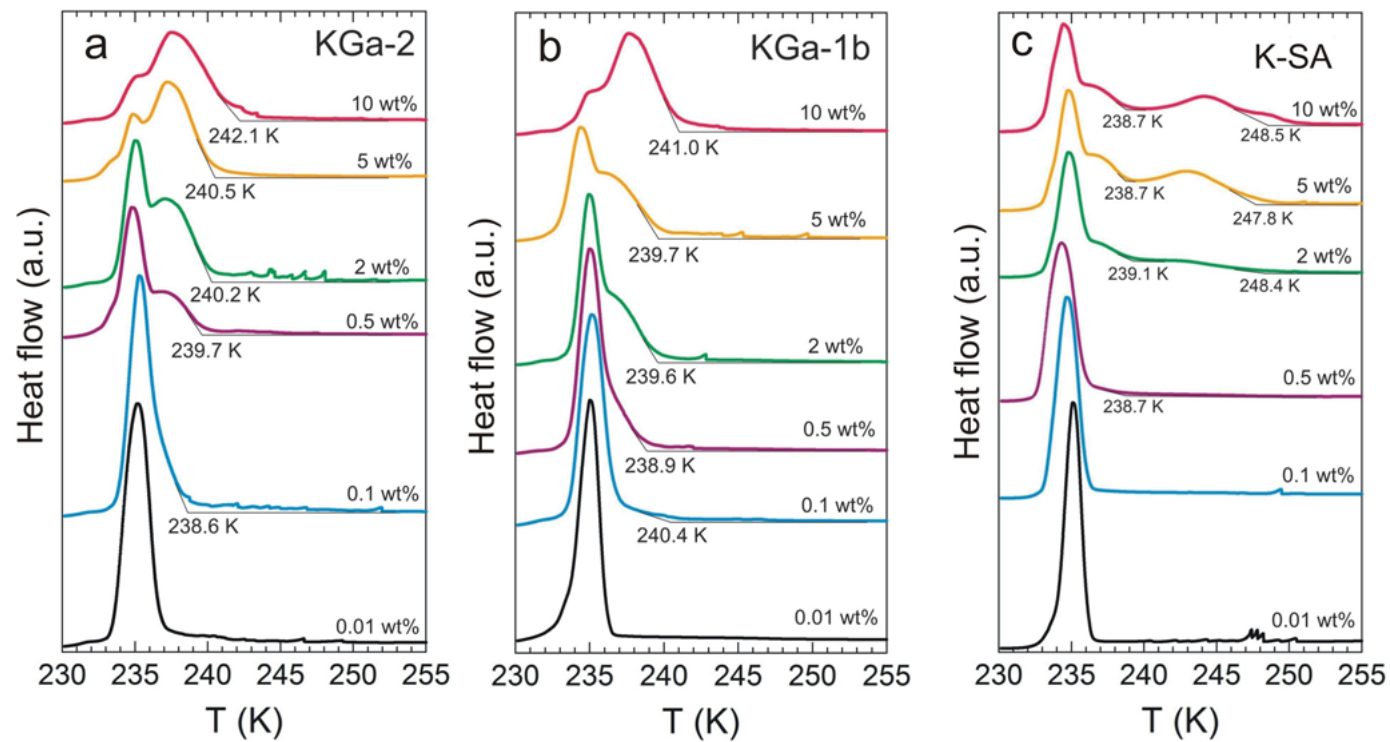

Fig. 3. DSC thermograms of KGa-2 (panel a), KGa-1b (panel b) and K-SA (panel c). Curves are shown with different offsets for clarity. Suspension concentrations and onsets of heterogeneous freezing are indicated above and below the curves, respectively. The onset of the freezing peaks $\left(T_{\mathrm{O}}\right)$ is given by the intersection of the two tangent lines (thin black lines) for each curve.

\section{Results}

\subsection{Emulsion experiments}

\subsubsection{Kaolinite}

Figure $3 a-c$ shows the DSC freezing curves of the three investigated types of kaolinite for concentrations ranging from 0.01 to $10 \mathrm{wt} \%$ in suspension. The lowest mineral concentrations show one freezing peak with onset temperatures in the range $236.2-236.6 \mathrm{~K}$. This freezing temperature is typical for homogeneous ice nucleation and in good agreement with freezing of pure water emulsion samples prepared by the same procedure (236.1-236.3 K). Variations of this homogeneous freezing temperature reflect the reproducibility of emulsion preparation, e.g. by variations in droplet size distribution. DSC peaks that appear at higher temperatures are considered to originate from heterogeneous freezing on the clay and dust material. Small sharp peaks - so-called spikes - in the DSC thermograms are caused by freezing of single large droplets and are not reproducible features of a DSC scan. Therefore, they are not considered for further evaluation.

Figure 3a shows the DSC curves of the high defect kaolinite KGa-2 from the Clay Mineral Society. The lowest concentration for which heterogeneous freezing can be observed is $0.1 \mathrm{wt} \%$ with a heterogeneous freezing onset at $T_{\mathrm{on}}^{\text {std }}=$ $238.6 \mathrm{~K}$. When the dust concentration increases, the intensity of the heterogeneous freezing peak also increases, and the onset shifts by 3.5 to $242.1 \mathrm{~K}$ at $10 \mathrm{wt} \%$. A similar shift was also detected for Arizona Test Dust (ATD) in similar DSC experiments with an onset increasing from $247.4 \mathrm{~K}$ for
$0.01 \mathrm{wt} \%$ to $252.4 \mathrm{~K}$ for $10 \mathrm{wt} \%$, corresponding to a shift of $5 \mathrm{~K}$ (Marcolli et al., 2007).

Figure $3 \mathrm{~b}$ shows the DSC results obtained for the lowdefect kaolinite KGa-1b. Again $0.1 \mathrm{wt} \%$ represents the lowest suspended mineral concentration for which heterogeneous freezing can be observed. An increase in mineral concentrations from 0.1 via 0.5 to $10 \mathrm{wt} \%$ results in a minor increase in freezing onsets $T_{\mathrm{on}}^{\text {std }}$ from 240.4 via 238.9 to $241.0 \mathrm{~K}$, but all within the range of experimental uncertainty. These heterogeneous onset temperatures of $\mathrm{KGa}-1 \mathrm{~b}$ are in the same range as the ones of $\mathrm{KGa}-2$. At the highest mineral concentrations, $\mathrm{KGa}-1 \mathrm{~b}$ and $\mathrm{KGa}-2$ samples show quite narrow heterogeneous freezing signals that peak before the onset of homogeneous ice nucleation, indicating that heterogeneous ice nucleation is fading away before homogeneous ice nucleation sets in.

DSC curves for kaolinite from Sigma Aldrich, hereafter termed K-SA, are shown in Fig. 3c. Surprisingly, two heterogeneous freezing peaks appear: one which we term "standard" at temperatures similar to the ones of the samples from the Clay Mineral Society $\left(238.7 \mathrm{~K}<T_{\mathrm{on}}^{\text {std }}<239.1 \mathrm{~K}\right)$, and one which we term "special" at much higher temperatures ( $247.8 \mathrm{~K}<T_{\mathrm{on}}^{\mathrm{spcl}}<248.5 \mathrm{~K}$ ). The evaluation of the freezing peak at lower temperature is hampered because its onset overlaps with the tail of the preceding freezing peak. The freezing peaks with onsets at $\sim 239 \mathrm{~K}$ and $\sim 248 \mathrm{~K}$ are observed at lowest dust concentrations of 0.5 and $2 \mathrm{wt} \%$, respectively. A third peak seems to appear at higher temperature for the $10 \mathrm{wt} \%$ mineral concentration, but the data are noisy (not shown) and no onset is evaluable. This could suggest that at higher suspension concentrations dust aggregates 

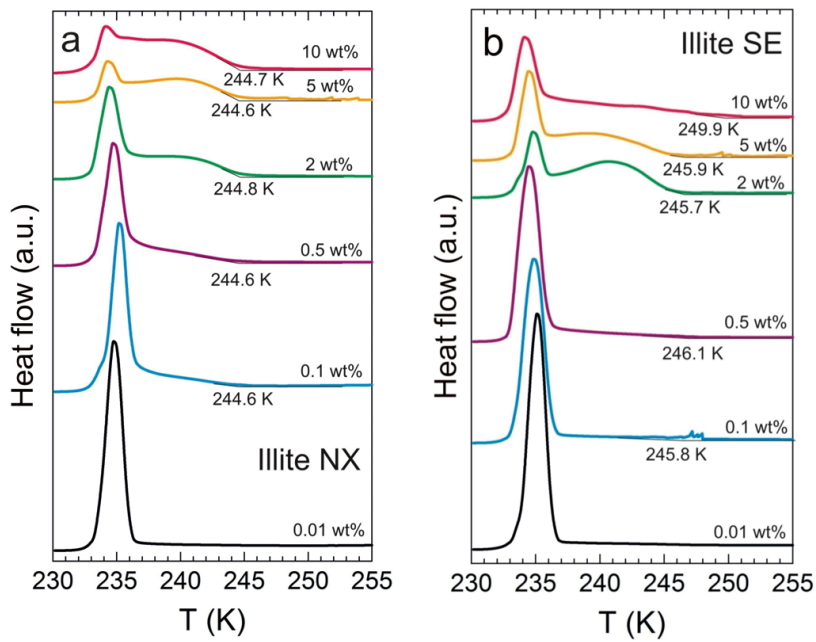

Fig. 4. DSC thermograms of Ill NX (panel a) and Ill SE (panel b). Curves are shown with different offsets for clarity. Suspension concentrations and onsets of heterogeneous freezing are indicated above and below the curves, respectively. The onset of the freezing peaks $\left(T_{\text {on }}\right)$ is given by the intersection of the two tangent lines (thin black curves) for each curve.

promote the formation of larger emulsion droplets freezing at higher temperatures. The presence of one additional heterogeneous freezing peak in K-SA might be due to the collection location or to the pre-treatment of the clay affecting the IN efficiency. Unfortunately, Sigma Aldrich does not provide more detailed information on their kaolinite characteristics, preventing further conclusions.

\subsubsection{Illite}

Figure $4 \mathrm{a}$ and $\mathrm{b}$ shows the DSC curves obtained for Illite NX and SE, respectively. Both types of illite show a heterogeneous freezing peak at a lowest dust concentration of $0.5 \mathrm{wt} \%$ with $244.6 \mathrm{~K}<T_{\mathrm{on}}^{\text {std }}<244.8 \mathrm{~K}$ (Ill NX) and $245.7 \mathrm{~K}<T_{\text {on }}^{\text {std }}<246.1 \mathrm{~K}$ (Ill SE). Ill SE also presents a second heterogeneous freezing peak at a dust concentration of $10 \mathrm{wt} \%$ with onset $T_{\mathrm{on}}^{\mathrm{spcl}}=249.9 \mathrm{~K}$. Ill SE contains a higher concentration of calcite, which might be a reason for the higher freezing temperature. However, calcite proved to be a poor IN in deposition nucleation experiments (Eastwood et al., 2008). Both illite samples exhibit broad freezing peaks that extend to homogeneous freezing temperatures suggesting that heterogeneous ice nucleation is still ongoing when homogeneous ice nucleation sets in. Ill NX and Ill SE are less uniform in composition than the kaolinite samples (see Table 1). This might result in higher freezing onsets and broader freezing peaks.

\subsubsection{Montmorillonite}

Four different types of montmorillonite were investigated: two natural samples from the Clay Mineral Society and two
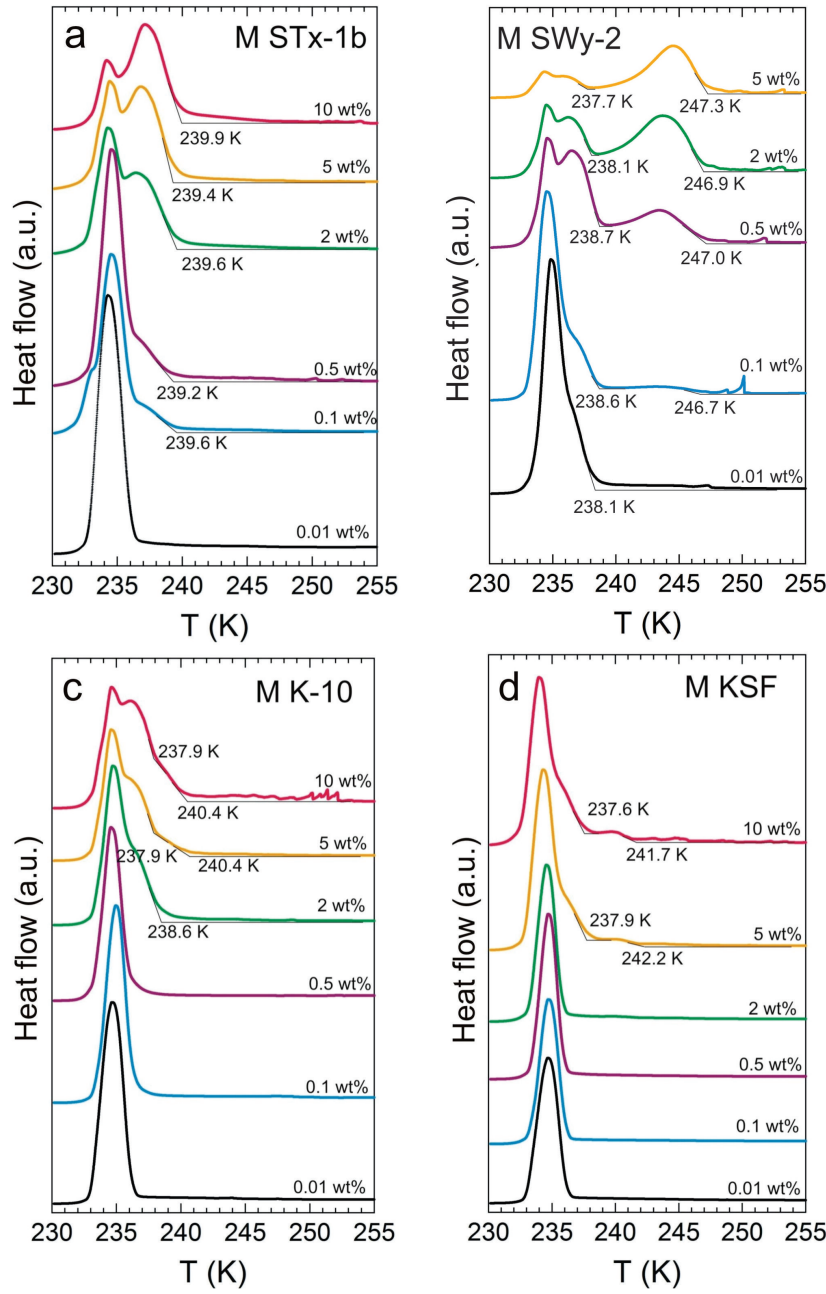

Fig. 5. DSC thermograms of $M S T x-1 b$ (panel a), M SWy-2 (panel b), M K-10 (panel c) and M KSF (panel d). Curves are shown with different offsets for clarity. Suspension concentrations and onsets of heterogeneous freezing are indicated above and below the curves, respectively. The onset of the freezing peaks $\left(T_{\mathrm{On}}\right)$ is given by the intersection of the two tangent lines (thin black curves) for each curve.

"acid-activated" montmorillonites from Sigma Aldrich. M STx-1b from Clay Mineral Society (Fig. 5a) shows a heterogeneous freezing peak at a lowest dust concentration of $0.1 \mathrm{wt} \%$ with onset in the range $239.2 \mathrm{~K}<T_{\text {on }}^{\text {std }}<239.9 \mathrm{~K}$ and a quite narrow peak width comparable to the ones of the kaolinite samples from the Clay Mineral Society.

The second natural sample, M SWy-2 (Clay Mineral Society), shown in Fig. 5b clearly presents a heterogeneous freezing peak even for the lowest suspension concentration of $0.01 \mathrm{wt} \%$ at an onset $237.7 \mathrm{~K}<T_{\mathrm{on}}^{\text {std }}<238.7 \mathrm{~K}$. A second heterogeneous freezing peak with onset between $T_{\mathrm{on}}^{\mathrm{spcl}}=$ 246.7 and $247.3 \mathrm{~K}$ appears at $0.1 \mathrm{wt} \%$. It was impossible to create a suspension of $10 \mathrm{wt} \%$, because a slurry formed that could not be emulsified. While M STx-1b presents interlayer 


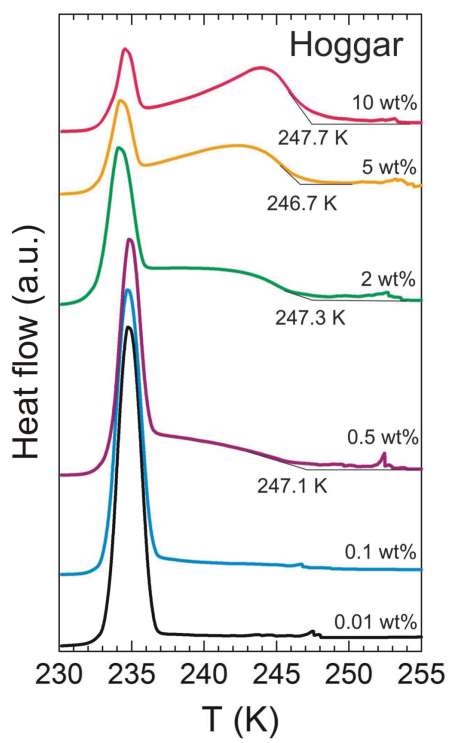

Fig. 6. DSC thermograms of a dust sample from Hoggar mauntains. Curves are shown with different offsets for clarity. Suspension concentrations and onsets of heterogeneous freezing are indicated above and below the curves, respectively. The onset of the freezing peaks $\left(T_{\mathrm{On}}\right)$ is given by the intersection of the two tangent lines (thin black curves) for each curve.

$\mathrm{Ca}^{2+}$ cations, M SWy-2 has $\mathrm{Na}^{+}$interlayer cations. This seems to be the major difference between the two clays, so that the different interlayer cations might be a reason for the second freezing peak of M SWy-2. Systematic ion-exchange experiments might be a way to support this hypothesis.

M K-10 and M KSF, two "acid-activated" montmorillonites from Sigma Aldrich, both require high concentrations to reveal heterogeneous freezing peaks. While most other investigated clays present detectable heterogeneous freezing onsets already at $0.1 \mathrm{wt} \%$ suspension concentration, $\mathrm{M} \mathrm{K}-10$ and M KSF require $2 \mathrm{wt} \%$ and $5-10 \mathrm{wt} \%$, respectively. This could be due to the acid treatment, which partially disrupts the crystal structure (Table 1). M K-10 in Fig. 5c shows two heterogeneous freezing peaks, the first appearing at $2 \mathrm{wt} \%$ with an onset in the range $237.9 \mathrm{~K}<T_{\text {on }}^{\text {std }}<238.6 \mathrm{~K}$, and the second at $5 \mathrm{wt} \%$ with onset at $T_{\mathrm{on}}^{\mathrm{spcl}}=240.4 \mathrm{~K}$. Figure $5 \mathrm{~d}$ for M KSF shows also two heterogeneous freezing peaks with onsets at $237.6 \mathrm{~K}<T_{\mathrm{on}}^{\mathrm{std}}<237.9 \mathrm{~K}$ and $241.7 \mathrm{~K}<T_{\mathrm{on}}^{\mathrm{spcl}}<$ $242.2 \mathrm{~K}$. In this case the heterogeneous freezing peaks appear only at the highest suspension concentrations (5-10 wt \%).

\subsubsection{Hoggar mountain dust}

As mentioned above, Hoggar Mountain dust is suited for emulsion experiments without prior treatment besides sieving, because it contains a large percentage of very small particles. Heterogeneous freezing peaks of the mineral dust sample collected from the Hoggar mountains (Fig. 6) appear broad for the lowest suspension concentration of $0.5 \mathrm{wt} \%$

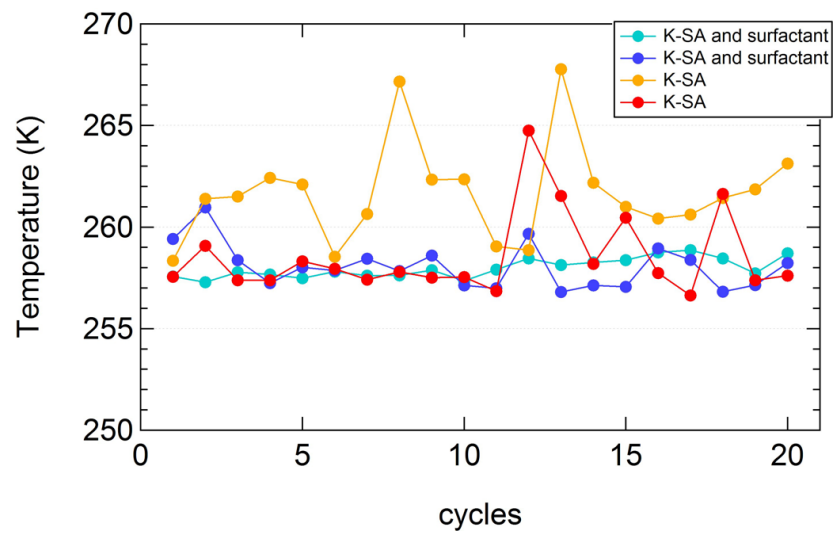

Fig. 7. Bulk measurements of freezing temperature for $5 \mathrm{wt} \% \mathrm{~K}-\mathrm{SA}$ suspensions mixed with lanolin (light and dark blue) and pure K-SA suspensions (red and orange). The median of the values shown here has been termed $T_{\text {med }}^{\text {best }}$.

with onsets between $T_{\mathrm{on}}^{\text {std }}=247.1$ and $247.7 \mathrm{~K}$. These onset values are higher than the ones of all other investigated clay minerals, showing the importance to investigate natural samples. On the other hand, the Hoggar onset temperatures are still lower than those of Arizona Test Dust (ATD) characterized by Marcolli et al. (2007). The illite clay minerals come closest to the Hoggar sample in terms of width and onset of the heterogeneous peak. This agrees well with the supposed mineral composition of the Hoggar dust with a large share of illite.

\subsection{Bulk measurements}

The emulsion freezing experiments were complemented by bulk experiments to assess the highest heterogeneous freezing temperatures that are reached when freezing of a large water volume is initiated by a single best IN (see also Hoyle et al., 2011). For all clay minerals and the Hoggar dust sample we performed up to twenty cooling and warming cycles with $5 \mathrm{wt} \%$ aqueous suspensions with sample masses of approximately $2.5 \mathrm{mg}$. Figure 7 shows the twenty consecutive cycles of two such experimental runs, each performed with a fresh bulk sample of K-SA. No systematic change in freezing temperature was detected between runs. This suggests that the freezing process does not significantly change the characteristics of the IN during experimental runs. Freezing occurred between $256 \mathrm{~K}$ and $269 \mathrm{~K}$. As expected from the sensitivity of a single best nucleus, the bulk experiments show a broad and much higher temperature range than observed for freezing of emulsion experiments.

To exclude the possibility that the much lower freezing temperatures obtained for emulsion freezing are caused by interactions between the lanolin surfactant and the clay surface (i.e. coating of the clay), we performed bulk experiments with $5 \mathrm{wt} \% \mathrm{~K}-\mathrm{SA}$ suspensions in the presence of lanolin. A mix of $80 \mathrm{wt} \%$ of the suspension and $20 \mathrm{wt} \%$ of lanolin 


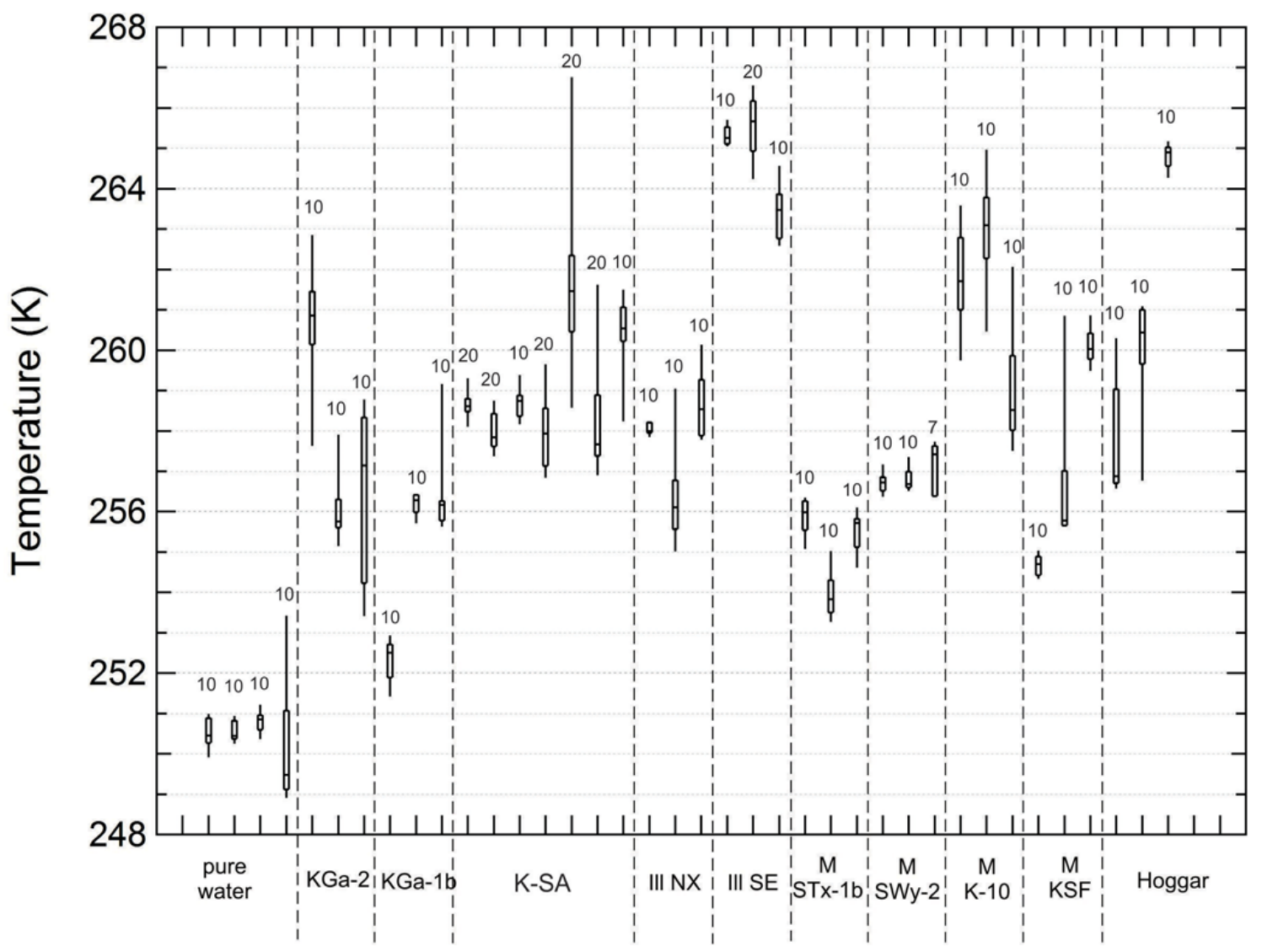

Fig. 8. Box and whisker plot of bulk measurements of the investigated samples with $5 \mathrm{wt} \%$ of suspended clay mineral (except pure water on the left). The upper and lower boarders of the box are given by the upper and lower quartile, respectively, and the horizontal line in the middle of the box shows the value of the median $\left(T_{\mathrm{med}}^{\mathrm{best}}\right)$. The highest and lowest values in a particular experiment are shown by the ends of the whiskers. Different clay minerals are separated by dashed vertical lines. The numbers on each box represent the number of cycles.

and mineral oil was stirred. In this proportion, no emulsion is formed and the water volume remains connected (bulk), while the surfactant is able to interact with the clay. Figure 7 shows that the freezing temperatures for 20 cycles of samples with and without surfactant are all in the same temperature range. From this we conclude that interactions with lanolin can be excluded as reason for the lower freezing temperature of emulsion samples.

The freezing temperature distributions of all investigated bulk samples are represented as box and whisker plots in Fig. 8. Each box and whisker plot represents the results obtained from an "experimental run", i.e. the up to 20 cooling and warming cycles performed with a particular sample. Several experimental runs were made with samples of the same suspension, to test the reproducibility of the results between samples of the same clay mineral type.

Also shown in Fig. 8 are results of bulk samples consisting of pure water, which typically freeze heterogeneously between $249.0 \mathrm{~K}$ and $253.5 \mathrm{~K}$ (Hoyle et al., 2011) due to the presence of minor impurities and interactions with the pan walls. This limits the significance of our bulk experiments to temperatures above $254 \mathrm{~K}$. It can be seen from Fig. 8 that all investigated $5 \mathrm{wt} \%$ suspensions initiate freezing at or above this threshold. The averaged median values of the freezing temperatures are $T_{\text {med }}^{\text {best }}=257.3 \mathrm{~K}$ for kaolinites, $261.6 \mathrm{~K}$ for illites, $257.4 \mathrm{~K}$ for montmorillonites, and $260.9 \mathrm{~K}$ for the Hoggar dust sample. Considering the large spread in freezing temperatures, a ranking of the IN efficiencies of the different clays based on this data is problematic. On the other hand, differences are evident when comparing bulk freezing temperatures of different types of the same clay mineral, e.g. the acid-treated M K-10 from Sigma-Aldrich freezes at significantly higher temperatures than the natural samples from the Clay Mineral Society. This last finding indicates that high bulk freezing temperatures do not necessarily require an intact crystal structure.

Figure 9 shows that reducing the suspension concentration in K-SA bulk samples by a factor of 10 and 100, (i.e. $0.5 \mathrm{wt} \%$ and $0.05 \mathrm{wt} \%$ suspensions), leads to freezing in a similar temperature range as for "pure water samples". Therefore, freezing cannot be unambiguously attributed to heterogeneous ice nucleation on the clay surface. The distinct 


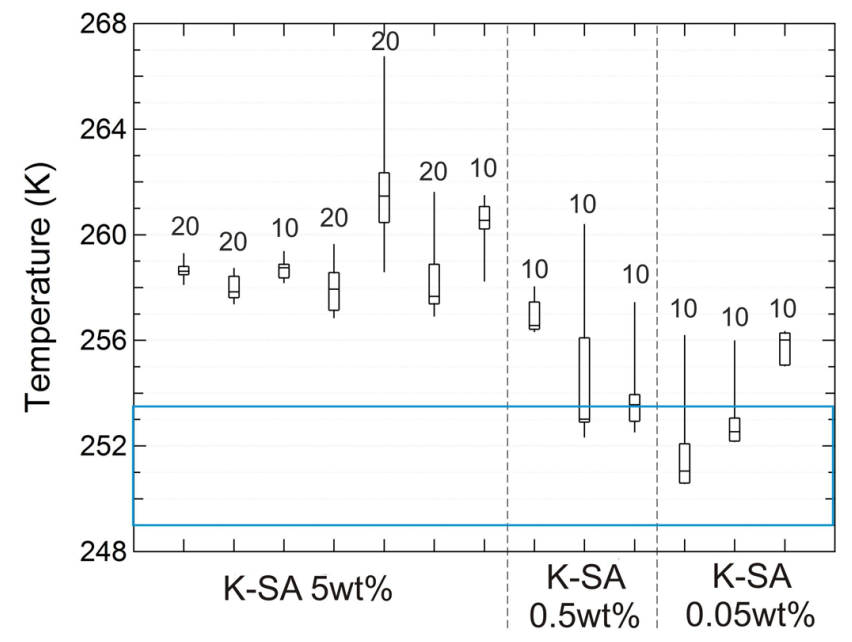

Fig. 9. Box and whisker plot of bulk measurements for K-SA suspensions with different concentrations. The blue rectangle represents the spread in pure water freezing temperatures. The numbers on each box represent the number of cycles.

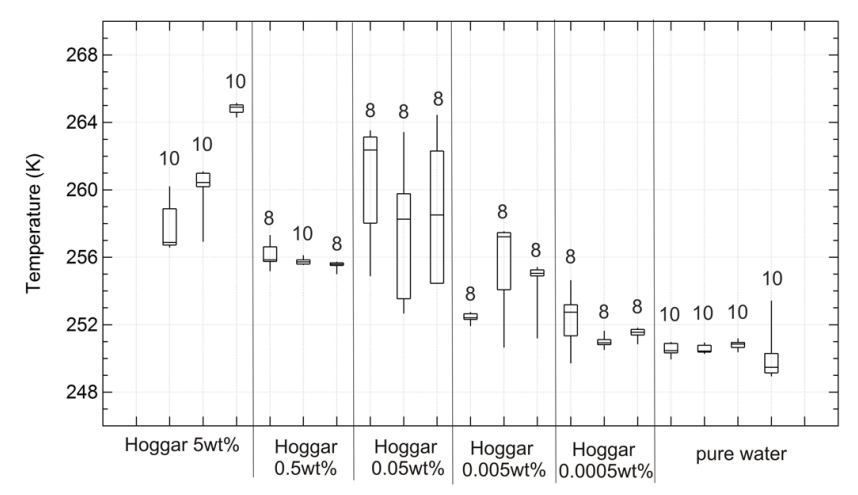

Fig. 10. Box and whisker plot of bulk measurements of Hoggar dust suspensions with different wt $\%$. The numbers on each box represent the number of cycles.

reduction of the lowest freezing temperature by $\sim 4 \mathrm{~K}$ for a decrease of the suspension concentration by a factor of 10 shows that indeed very few best IN are responsible for the freezing events occurring at the highest temperatures. Bulk samples with $5 \mathrm{wt} \%$ of K-SA contain approximately $10^{7}$ particles indicating that only about 1 per million of kaolinite particles lead to freezing above $254 \mathrm{~K}$. The reduction in average freezing temperature with decreasing suspension concentration is much less pronounced for the Hoggar sample (Fig. 10). The lowest suspension concentration for which heterogeneous freezing is still well discriminated from water freezing is $0.005 \mathrm{wt} \%$. From this, it can be estimated that 1 per 2700 particles are responsible for freezing above $254 \mathrm{~K}$ in the Hoggar sample.
Table 2. Summary of freezing peaks of emulsion and bulk experiments: onset freezing temperatures are given for standard and special sites, average of median freezing temperatures for best sites ( $5 \mathrm{wt} \%$ suspension concentration). Where the standard deviation is not shown, there were too few data for evaluation.

\begin{tabular}{llll}
\hline & \multicolumn{2}{c}{ Emulsions: } & \multicolumn{1}{c}{ Bulks: } \\
Clay mineral & $\begin{array}{l}\text { Standard sites } \\
T_{\text {on }}^{\text {std }}(\mathrm{K})\end{array}$ & $\begin{array}{l}\text { Special sites } \\
T_{\text {on }}^{\text {spl }}(\mathrm{K})\end{array}$ & $\begin{array}{l}\text { Best sites }(5 \mathrm{wt} \%) \\
T_{\text {med }}^{\text {best }}(\mathrm{K})\end{array}$ \\
\hline KGa-1b & $239.9 \pm 0.8$ & - & 255.2 \\
KGa-2 & $238.6-242.1^{*}$ & - & 257.9 \\
K-SA & $238.8 \pm 0.2$ & $248.2 \pm 0.4$ & 259.0 \\
Ill NX & $244.7 \pm 0.1$ & - & 257.6 \\
Ill SE & $245.9 \pm 0.2$ & 249.9 & 264.8 \\
M SWy-2 & $238.2 \pm 0.4$ & $247.0 \pm 0.2$ & 256.9 \\
M STx-1b & $239.5 \pm 0.3$ & - & 255.5 \\
M K10 & $238.1 \pm 0.4$ & 240.4 & 261.1 \\
M KSF & 237.8 & 242.0 & 256.8 \\
Hoggar & $247.2 \pm 0.4$ & - & 260.7 \\
\hline
\end{tabular}

* This clay mineral presents a shift in the onset temperatures depending on concentration.

\section{Discussion}

\subsection{Freezing temperatures of emulsions and bulk samples}

When taking bulk and emulsion freezing experiments together, the heterogeneous freezing of the investigated clay minerals and the Hoggar dust sample spans the entire temperature range from well over $260 \mathrm{~K}$ down to the onset of homogeneous ice freezing. Emulsion experiments revealed distinct freezing peaks with almost concentration-independent onset temperatures. A summary of standard, special and best sites $\left(T_{\mathrm{on}}^{\mathrm{std}}, T_{\mathrm{on}}^{\mathrm{spcl}}, T_{\mathrm{med}}^{\text {best }}\right)$ of all investigated clays and the Hoggar dust sample is given in Table 2.

Figure 11a shows the onset freezing temperatures for emulsion measurements plotted as a function of the BET surface areas (Table 1) per droplet. The dashed lines represent calculated freezing onsets for a frozen fraction of $1 \%$ using Classical Nucleation Theory (CNT, parameterization of Zobrist et al., 2007) with different contact angles. CNT describes ice nucleation as stochastic process and predicts an increase of freezing temperature with increasing heterogeneous surface given by the slope of the dashed lines. The heterogeneous freezing peaks of the emulsions show almost constant onset temperatures with the exception of the kaolinite KGa-2 clay mineral, which exhibits an onset shift from 238.6 to $242.1 \mathrm{~K}$ with increasing suspension concentrations from 0.1 to $10 \mathrm{wt} \%$. However, given the experimental uncertainties represented by the error bars, there is no direct conflict between the almost concentration-independent constant experimental $T_{\mathrm{on}}^{\text {std }}$ and CNT.

Contact angles of the standard peaks of kaolinites and montmorillonites correspond to $90-110^{\circ}$ and $100-120^{\circ}$, respectively. Since kaolinites and montmorillonites show quite 

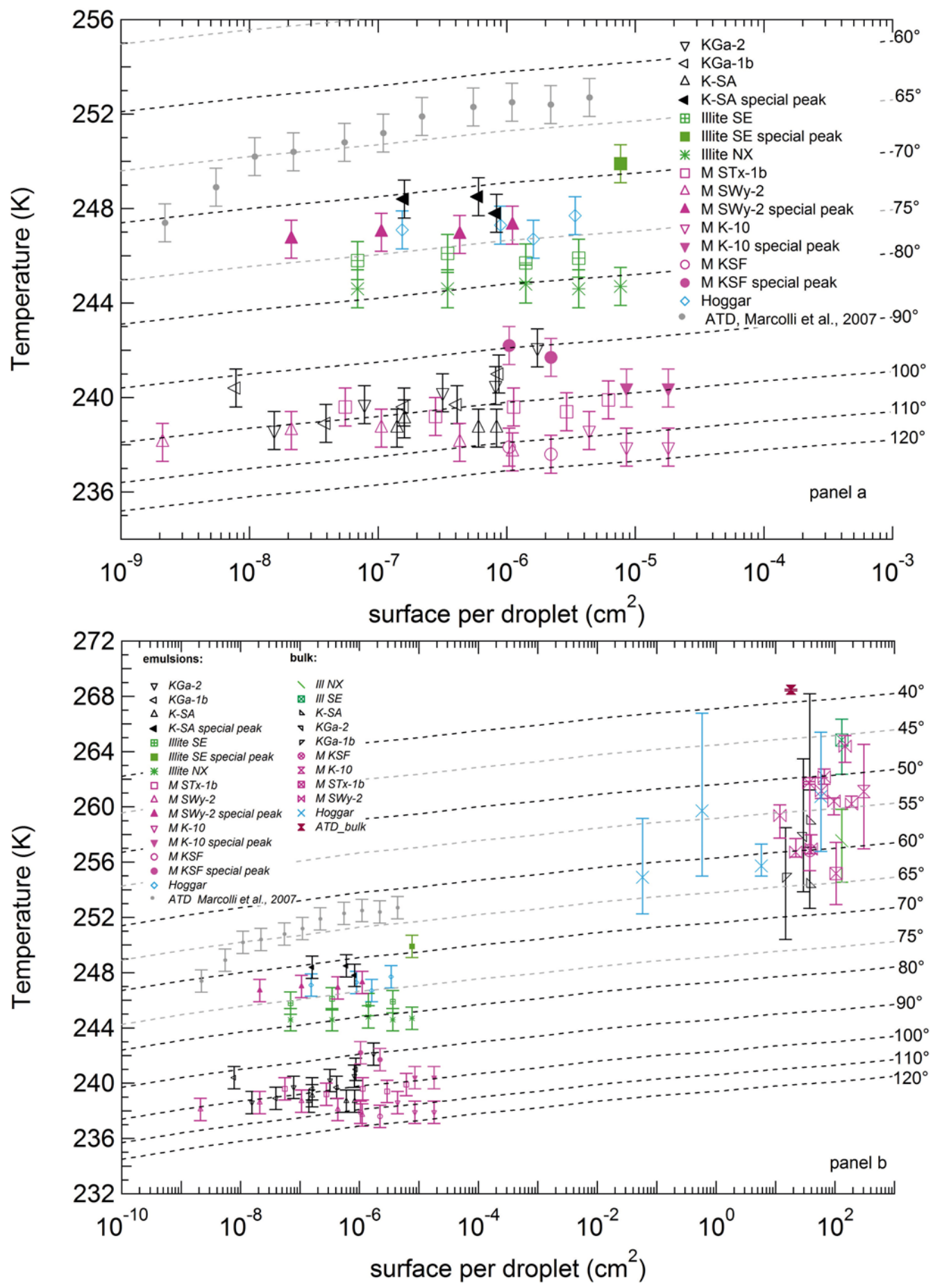

Fig. 11. Freezing temperatures as a function of the BET surface area per droplet. (a) Emulsion experiments. Different clay minerals are shown in different colours. Open and solid symbols represent standard and special peaks, $T_{\mathrm{on}}^{\text {std }}$ and $T_{\mathrm{on}}^{\text {spcl }}$, respectively. Error bars indicate the uncertainties associated with the emulsion reproducibility. (b) Emulsion and bulk experiments. Symbols represent the average of median freezing temperatures for bulk experiments (see Table 2 for the $5 \mathrm{wt} \%$ suspensions), $T_{\text {med }}^{\text {best }}$ vertical bars represent the spread in these temperatures between freezing cycles. Grey dashed lines in both panels: calculated $T_{\text {on }}$ for a frozen droplet fraction of 0.01 (i.e. onset) using classical nucleation theory (CNT, parameterization of Zobrist et al., 2007) with the contact angle indicated on the right side. For emulsion experiments, the BET surface area per droplet was calculated by dividing the BET surface area present in an emulsion sample by the number of droplets present in an emulsion sample. The BET surface areas of Arizona Test Dust experiments from Marcolli et al. (2007) (grey dots) were calculated with values taken from Teipel et al. (2008). 
narrow freezing peaks in the DSC emulsion experiments, these numbers should be representative for the whole distribution of contact angles responsible for standard freezing. The standard peaks in illites and the Hoggar dust samples are much broader. The onset freezing temperatures correspond to contact angles ranging from $75-80^{\circ}$ and fall into a similar range as the contact angles of the special peaks of K-SA and M SWy-2. Since the standard peaks in illites and the Hoggar dust sample extend to the onset of homogeneous freezing, these samples likely also contain nucleation sites with contact angles in the same range as standard peaks of montmorillonites and kaolinites $\left(90-120^{\circ}\right)$.

The bulk freezing experiments show a scatter of 2.6-7.2 K between median freezing temperatures of individual experimental runs performed with the same clay mineral type. The largest scatter between highest and lowest freezing temperature of one experimental run varies from 258.5 to $266.8 \mathrm{~K}$. This scatter in temperatures is comparable to the one found in similar freezing experiments on volcanic ash bulk samples described by Hoyle et al. (2011) and consistent with results discussed by Vali and Stansbury (1966). The interpretation given by these authors is that "the characteristics of a particular nucleating site determine a range of possible nucleation temperatures for that site", this means that each site shows a probability function to freeze in a certain temperature range. In a recent paper Vali (2008) observed run-to-run changes in heterogeneous freezing temperatures of single droplets containing suspensions of a soil sample of $<1^{\circ} \mathrm{C}$ for the majority of the events. His Table 1 (row 1) shows that $50 \%$ of the changes were within $\pm 0.27^{\circ} \mathrm{C}$ and $80 \%$ within $\pm 0.53^{\circ} \mathrm{C}$. For comparison, the run-to-run changes in freezing temperatures of the droplets containing suspensions of clay minerals (results shown in Fig. 8) and of the Hoggar dust samples (results shown in Fig. 10) were larger, namely $50 \%$ of the changes were within $\pm 0.6^{\circ} \mathrm{C}$ and $80 \%$ within $\pm 1.8^{\circ} \mathrm{C}$ as an average of all clay minerals, and $50 \%$ of the changes were within $\pm 0.6^{\circ} \mathrm{C}$ and $80 \%$ within $\pm 2.1^{\circ} \mathrm{C}$ for the Hoggar dust sample.

In Fig. 11b emulsion and bulk freezing temperatures are shown together as a function of BET surface area. In CNT using the parameterization of Zobrist et al. (2007), the bulk freezing temperatures correspond to contact angles ranging from $40-70^{\circ}$. This suggests that freezing temperatures of bulk samples cannot be explained by scaling the emulsion freezing results to larger surface areas but that they have to originate from a different class of sites.

Assuming that 1-10 particles are responsible for freezing in bulk experiments, there is only $0.01-1$ best sites per $\mathrm{cm}^{2}$ of clay surface. These best sites are so infrequent that they are below the detection limit of the emulsion experiments. The freezing temperatures of the bulk samples show a large scatter between samples, which we attribute to the low number of best IN leading to a large variation in quality of the best IN present in a sample.

\subsection{Comparison with literature}

Freezing temperatures of our samples cover a similar temperature range as observed in older studies by Pitter and Pruppacher (1973) and Hoffer (1961). Hoffer (1961) reported freezing of $25-170 \mu \mathrm{m}$ droplets consisting of montmorillonite suspensions (with unspecified concentrations) between $237.7-260.0 \mathrm{~K}$, of kaolinite suspensions between 238.2-254.2 K, and of illite suspensions between 246.2255.2 K. Pitter and Pruppacher (1973) observed freezing of $325 \mu \mathrm{m}$ droplets of kaolinite suspensions between 243.2$259.2 \mathrm{~K}$ and of montmorillonite suspensions between $245.2-$ $261.2 \mathrm{~K}$. These authors do not give information concerning their suspension concentrations and type of clay minerals, thus preventing a direct comparison. We can only state that sample volumes and freezing onsets of these older studies cover a similar range as our bulk samples. Therefore, onset freezing temperatures of these previous studies should not be taken as IN efficiency of average clay particles. This conclusion is corroborated by more recent studies that found much lower freezing onsets for their experimental conditions: $\mathrm{Zu}$ beri et al. (2002) measured heterogeneous nucleation of ice in aqueous ammonium sulfate droplets of the size range from $10-55 \mu \mathrm{m}$ containing numerous particles of kaolinite from Fluka (which corresponds with K-SA from Sigma Aldrich) and of montmorillonite (M K-10). Extrapolation to the pure water droplet case yielded average freezing temperatures of approximately $242 \mathrm{~K}$ for both clay mineral types. This freezing temperature falls in between the freezing temperatures of the standard and the special peaks of K-SA and M K10 and might indicate that for the concentration and particle size range that Zuberi et al. (2002) used in their experiments, freezing occurred sometimes on a standard and sometimes on a special nucleation site of the clay minerals. Lüönd et al. (2010) report on the onset of droplet freezing at $243.2 \mathrm{~K}$ and median freezing temperatures of $240.2 \mathrm{~K}$ and $238.2 \mathrm{~K}$ for droplets containing one $800 \mathrm{~nm}$ and one $200 \mathrm{~nm}$ diameter kaolinite particle (K-SA from Sigma Aldrich), respectively. These median freezing temperatures correspond well with $T_{\mathrm{on}}^{\text {std }}$ of K-SA in our experiments, indicating that freezing dominantly occurs on standard sites when only one clay particle per droplet is present. A tail to higher freezing temperatures that appears for the $800 \mathrm{~nm}$ diameter sample might be interpreted as arising from heterogeneous freezing on special sites for this largest investigated particle size. Murray et al. $(2010,2011)$ measured median nucleation temperatures increasing from $236 \mathrm{~K}$ to $240.8 \pm 0.6 \mathrm{~K}$ for $10-40 \mu \mathrm{m}$ droplets of kaolinite suspensions (KGa-1b), when dust concentrations increased from 0.005 to $1 \mathrm{wt} \%$, and constant freezing at $245.8 \pm 0.6 \mathrm{~K}$ for montmorillonite suspensions (M SWy-2) covering the same droplet and concentration range. These results are in good agreement with our own findings, where KGa-1b shows $238.9 \mathrm{~K}<T_{\text {on }}^{\text {std }}<$ $241.0 \mathrm{~K}$. There is a slight shift to higher temperatures with increasing concentrations, however within the range of our 
measurement uncertainties. Mean nucleation temperatures of $245.8 \pm 0.6 \mathrm{~K}$ for M SWy-2 coincide well with freezing on special sites for this clay mineral. Broadley et al. (2012) measured freezing onset temperatures from $246 \mathrm{~K}$ to the homogeneous regime $(236 \mathrm{~K})$ for Ill NX with droplet diameters between $10 \mu \mathrm{m}$ and $56 \mu \mathrm{m}$, when dust concentration decreases from 1.44 to $0.007 \mathrm{wt} \%$. These results are in good agreement with our findings, $244.6 \mathrm{~K}<T_{\text {on }}^{\text {std }}<244.8 \mathrm{~K}$ and broad freezing peaks for Ill NX.

These results show that immersion freezing temperatures of clay minerals strongly depend on the amount of clay mineral present in the droplets and the exact characteristics (location of collection and pre-treatment) of the clay mineral. Results obtained from different groups with different setups are indeed in good agreement when the type of the clay is the same and the loading of the droplets with particles is comparable.

\subsection{Occurrence probability of sites}

Table 3 shows the comparison of calculated and measured droplet fractions freezing heterogeneously. For DSC emulsion measurements the water fraction freezing heterogeneously was quantified as the ratio between the area below the heterogeneous peak and the area below the homogeneous and heterogeneous peaks. This fraction is termed $f_{2}$ in Table 3. It can be compared to the fraction of droplets in the emulsion samples containing dust particles. The average number of dust particles per droplet, $N$, was calculated as the ratio between the number of particles and the total number of droplets derived from the size distributions of the particles (Table 1) and the size distribution of the droplets in the emulsion, respectively. The volume fraction, which potentially freezes heterogeneously, was calculated on the basis of the droplet volume size distribution taking into account that the degree of occupation of particles scales with droplet size. This fraction is termed $f_{2}^{\text {std }}$ or $f_{2}^{\text {spcl }}$ in Table 3 , for occupation with particles carrying standard or special sites, respectively.

Our calculations suggest that droplets in the higher concentrated clay mineral emulsions are on average filled with several particles $(N)$ and that for the $10 \mathrm{wt} \%$ concentrations almost complete heterogeneous freezing should occur. On the other hand, the calculations of the fraction freezing heterogeneously (i.e. $f_{1}$ ) generally overestimate the fraction of droplets that freezes heterogeneously in the experiments, i.e. $f_{1}>f_{2}^{\text {std }}+f_{2}^{\text {spcl }}$. One potential reason for this discrepancy might be aggregation of the clay particles in the emulsion so that more droplets are empty than our calculations suggest. Strong aggregation at $\mathrm{pH}$ below 7 is indeed reported for kaolinites (Kretzschmar et al., 1998; Tombácz et al., 2004; Tombácz and Szekeres, 2006). In a recent paper, Wheeler and Bertram (2012) determined a median diameter for KSA of $8 \mu \mathrm{m}$ by measuring aqueous suspensions using static laser light scattering. For the same clay mineral suspended in air using a fluidized bed aerosol generator we determined a mean diameter of $446.8 \mathrm{~nm}$, supporting that kaolinites suspended in water indeed form aggregates. Assuming an average particle size of $8 \mu \mathrm{m}$, the calculated volume fractions that potentially freeze heterogeneously, $f_{1}$, would even be much too low. Lüönd et al. (2010) observed heterogeneous freezing of approximately $80 \%$ of droplets containing one kaolinite (K-SA) particle with diameter of 200 and $400 \mathrm{~nm}$, and $100 \%$ when droplets contained an $800 \mathrm{~nm}$ particle. This indicates that almost all droplets that contain a K-SA particle indeed freeze heterogeneously.

Coagulation in montmorillonites is much less pronounced than in kaolinites (Tombácz and Szekeres, 2006). In dilute aqueous solutions, sodium montmorillonite forms a stable sol of delaminated particles that turns into a gel at concentrations above $\sim 3 \mathrm{wt} \%$ (Abend and Lagaly, 2000). The relatively good agreement of calculated and measured volume fractions of water freezing heterogeneously in the DSC emulsion experiments of M SWy-2 (i.e. $f_{1} \approx f_{2}^{\text {std }}+f_{2}^{\text {spcl }}$ ) confirms that this clay mineral does not aggregate under our experimental conditions and that the size distributions of droplets and particles are both valid. Calcium montmorillonites have a higher tendency to coagulate than sodium montmorillonites, which might explain the larger discrepancies between calculated and measured heterogeneous freezing volume fractions for the calcium montmorillonite $\mathrm{M}$ STx-1b. Assuming a similarly low degree of aggregation for M K-10 and M KSF, the low heterogeneous peaks of these montmorillonites indicates that the acid treatment has indeed strongly decreased the capacity of these montmorillonites to induce heterogeneous freezing.

Our calculations show that droplets in illite emulsions with suspension concentrations of $5 \mathrm{wt} \%$ or higher should on average contain at least one clay particle. There is no clear information available whether these clay minerals aggregate in suspensions. The DSC thermograms of illites show that heterogeneous nucleation is still ongoing when homogeneous nucleation sets in. We therefore assume that a part of the droplets in these emulsions indeed freeze homogeneously although they contain illite particles.

The calculated number of particles per droplet is much lower for the Hoggar dust sample reflecting the coarser nature of this Saharan dust sample compared with the clay minerals (see Table 1). For this natural mineral dust the calculation even underestimates the relative intensity of the heterogeneous peak in the DSC thermograms (i.e. $f_{1}<f_{2}^{\text {std }}+$ $f_{2}^{\text {spcl }}$ ). We attribute this underestimation to the experimental uncertainties connected with the determination of the size distribution of the droplets and the particles. For this sample, one can assume that droplets that contain a dust particle indeed freeze heterogeneously.

\subsection{Origin of active sites}

Our analysis of emulsion and bulk freezing experiments suggests that nucleation in clay minerals occurs on three 
Table 3. Percentage of activated droplets depending on the mass concentration of the clay in suspension for all the minerals studied in this work.

\begin{tabular}{|c|c|c|c|c|c|c|c|}
\hline \multirow[t]{2}{*}{ Mineral } & \multirow{2}{*}{$\begin{array}{l}\text { Suspension } \\
\text { concentration } \\
(\mathrm{wt} \%)\end{array}$} & \multirow{2}{*}{$\begin{array}{l}\text { Average number } \\
\text { of particles per } \\
\text { droplet, } N\end{array}$} & \multirow{2}{*}{$\begin{array}{l}\text { Calculated volume } \\
\text { fraction freezing } \\
\text { heterogeneously, } f_{1}\end{array}$} & \multicolumn{2}{|c|}{ DSC Standard peak } & \multicolumn{2}{|c|}{ DSC Special peak } \\
\hline & & & & $\begin{array}{l}\text { onset } \\
T_{\mathrm{On}}^{\mathrm{std}}(\mathrm{K})\end{array}$ & $\begin{array}{l}\text { normalized } \\
\text { area, } f_{2}^{\text {std }}\end{array}$ & $\begin{array}{l}\text { onset } \\
T_{\mathrm{On}}^{\mathrm{spcl}}(\mathrm{K})\end{array}$ & $\begin{array}{l}\text { normalized } \\
\text { area, } f_{2}^{\text {spcl }}\end{array}$ \\
\hline \multirow[t]{5}{*}{ KGa-2 } & 0.1 & 0.09 & 0.55 & 238.6 & 0.26 & - & - \\
\hline & 0.5 & 0.45 & 0.83 & 239.7 & 0.34 & - & - \\
\hline & 2 & 1.82 & 0.95 & 240.2 & 0.53 & - & - \\
\hline & 5 & 4.70 & 0.98 & 240.5 & 0.75 & - & - \\
\hline & 10 & 9.92 & 0.99 & 242.1 & 0.84 & - & - \\
\hline \multirow[t]{5}{*}{ KGa-1b } & 0.1 & 0.15 & 0.66 & 240.4 & 0.09 & - & - \\
\hline & 0.5 & 0.74 & 0.88 & 238.9 & 0.23 & - & - \\
\hline & 2 & 3.02 & 0.97 & 239.6 & 0.37 & - & - \\
\hline & 5 & 7.78 & 0.99 & 239.7 & 0.41 & - & - \\
\hline & 10 & 16.43 & 1.00 & 241.0 & 0.85 & - & - \\
\hline \multirow[t]{5}{*}{ K-SA } & 0.1 & 0.02 & 0.22 & -* $^{*}$ & - & - & - \\
\hline & 0.5 & 0.10 & 0.57 & 238.7 & 0.06 & - & - \\
\hline & 2 & 0.39 & 0.82 & 239.1 & 0.22 & 248.4 & 0.18 \\
\hline & 5 & 1.01 & 0.91 & 238.7 & 0.25 & 247.8 & 0.37 \\
\hline & 10 & 2.13 & 0.96 & 238.7 & 0.23 & 248.5 & 0.39 \\
\hline \multirow[t]{5}{*}{ Ill SE } & 0.1 & 0.07 & 0.50 & 245.8 & 0.17 & - & - \\
\hline & 0.5 & 0.37 & 0.81 & 246.1 & 0.13 & - & - \\
\hline & 2 & 1.49 & 0.94 & 245.7 & 0.69 & - & - \\
\hline & 5 & 3.85 & 0.98 & 245.9 & 0.54 & - & - \\
\hline & 10 & 8.13 & 0.99 & - & 0.20 & 249.9 & 0.09 \\
\hline \multirow[t]{5}{*}{ Ill NX } & 0.1 & 0.03 & 0.32 & 244.6 & 0.21 & - & - \\
\hline & 0.5 & 0.17 & 0.68 & 244.6 & 0.30 & - & - \\
\hline & 2 & 0.68 & 0.88 & 244.8 & 0.48 & - & - \\
\hline & 5 & 1.75 & 0.95 & 244.6 & 0.71 & - & - \\
\hline & 10 & 3.70 & 0.97 & 244.7 & 0.77 & - & - \\
\hline \multirow[t]{5}{*}{ M STx-1b } & 0.1 & 0.03 & 0.33 & 239.6 & 0.10 & - & - \\
\hline & 0.5 & 0.17 & 0.69 & 239.2 & 0.18 & - & - \\
\hline & 2 & 0.71 & 0.88 & 239.6 & 0.52 & - & - \\
\hline & 5 & 1.83 & 0.95 & 239.4 & 0.64 & - & - \\
\hline & 10 & 3.87 & 0.98 & 239.9 & 0.78 & - & - \\
\hline \multirow[t]{5}{*}{ M Swy-2 } & 0.01 & 0.007 & 0.09 & 238.1 & 0.22 & - & - \\
\hline & 0.1 & 0.07 & 0.49 & 238.6 & 0.20 & 246.7 & 0.06 \\
\hline & 0.5 & 0.35 & 0.80 & 238.7 & 0.45 & 247.0 & 0.29 \\
\hline & 2 & 1.42 & 0.93 & 238.1 & 0.26 & 246.9 & 0.56 \\
\hline & 5 & 3.67 & 0.97 & 237.7 & 0.12 & 247.3 & 0.76 \\
\hline \multirow[t]{5}{*}{ M K-10 } & 0.1 & 0.04 & 0.36 & - & - & - & - \\
\hline & 0.5 & 0.20 & 0.72 & - & - & - & - \\
\hline & 2 & 0.82 & 0.89 & 238.6 & 0.32 & - & - \\
\hline & 5 & 2.11 & 0.96 & 237.9 & 0.39 & 240.4 & 0.10 \\
\hline & 10 & 4.45 & 0.98 & 237.9 & 0.51 & 240.4 & 0.12 \\
\hline \multirow[t]{5}{*}{ M KSF } & 0.1 & 0.05 & 0.40 & - & - & - & - \\
\hline & 0.5 & 0.23 & 0.74 & - & - & - & - \\
\hline & 2 & 0.95 & 0.91 & - & - & - & - \\
\hline & 5 & 2.45 & 0.96 & 237.9 & 0.20 & 242.2 & 0.02 \\
\hline & 10 & 5.17 & 0.99 & 237.6 & 0.17 & 241.7 & 0.05 \\
\hline \multirow[t]{5}{*}{ Hoggar } & 0.1 & 0.0014 & 0.018 & - & - & - & - \\
\hline & 0.5 & 0.007 & 0.09 & 247.1 & 0.34 & - & - \\
\hline & 2 & 0.03 & 0.29 & 247.3 & 0.43 & - & - \\
\hline & 5 & 0.07 & 0.51 & 246.7 & 0.68 & - & - \\
\hline & 10 & 0.16 & 0.68 & 247.7 & 0.78 & - & - \\
\hline
\end{tabular}

* No heterogeneous peak detected. 
different types of sites, standard, special and best sites, with characteristic temperatures $T_{\mathrm{on}}^{\mathrm{std}}, T_{\mathrm{on}}^{\mathrm{spcl}}$ and $T_{\text {med }}^{\text {best }}$, respectively.

The standard peaks in montmorillonites and kaolinites are narrow and at similar temperatures, probably caused by similar surface features. Standard sites seem to be very frequent in natural clay minerals provided by the Clay Mineral Society such that nearly all clay particles induce heterogeneous freezing on standard sites. Destruction of the crystal lattice by acid treatment (M K-10, and M KSF) seems to reduce their number so that a part of the particles that were exposed to acids lose their ability to act as IN. Acid treatment appears to mostly affect the edges of the clay particles (Suarez Barrios et al., 2001). We therefore speculate that mainly the edges are involved in ice nucleation on standard sites. This argumentation gains some support by grand canonical Monte Carlo calculations performed by Croteau et al. (2008) that showed water adsorption on Al-surfaces and both protonated and unprotonated edges of kaolinite at atmospherically relevant relative humidities. However, the hexagonal pattern of water that adsorbed on the Al-surface and the basal plane of ice Ih showed a misfit strain. Hence, the ring structures that form on the Al-surface are not expected to be good buildingblocks for ice nucleation, rather ice nucleation might occur on the edges.

The standard peaks of illite and the Hoggar samples are much broader and extend to higher temperatures than the ones of kaolinite and montmorillonite. This might be related to the defective character of the crystal structure or to the mixture of minerals present in the illite and the Hoggar dust samples leading to less uniform surfaces with higher numbers of random defects that also might act as good sites for ice nucleation.

Several clay minerals showed a second heterogeneous freezing peak at higher temperatures for higher concentrations in emulsion experiments. These special peaks are not present in all types of the investigated clay: e.g. K-SA shows a second freezing peak at higher temperatures, while KGa- $1 \mathrm{~b}$ and KGa-2 do not. They therefore do not seem to be related to the regular crystal structure of the clay minerals, but rather to sites or surface structures that are typical for a certain type of a clay mineral. Since the special peaks are also quite narrow, they are rather not related to random defects. In the case of the montmorillonite M SWy-2 the exchangeable cations might play a role, however more experiments are needed to establish such a relationship.

A similar behaviour of the special peak was also detected by Niedermeier et al. (2011) for ATD quasi monodisperse particles in the immersion mode. Pure ATD particles nucleated ice over a broad temperature range with their freezing behaviour being separated into two freezing branches. Moreover Niedermeier et al. (2011) also observed that the branch at higher temperature significantly decreased once the particles were coated with sulphuric acid and therefore speculated that ATD particles have surface features which are affected by the acid treatment. However such a special peak was not detected by Marcolli et al. (2007) for immersion freezing experiments with polydisperse ATD particles.

All investigated clay minerals and the Hoggar dust sample exhibit a low number of best sites, which induce freezing above $254 \mathrm{~K}$ as could be shown in the bulk experiments. These best sites are very infrequent. They should not be mistaken as "heterogeneous IN efficiency" of these clay materials, as has erroneously been done in the past (Pitter and Pruppacher, 1973, and Hoffer, 1961). Such sites seem to be more abundant, when the crystal lattice is partly destroyed as the comparison of the montmorillonite samples suggests. The best sites are therefore most probably not related to the regular crystal lattice of the clay minerals, but due to random defects or to impurities such as lead inclusions (Cziczo et al., 2009) or biological residues (Conen et al., 2011).

\subsection{Atmospheric implication}

The number concentration of best IN in a bulk sample can be related to the amount of dust in an air parcel (Hoyle et al., 2011). Atmospheric dust concentrations (mass densities) span a wide range from $0.01-1000 \mu \mathrm{g} \mathrm{m}^{-3}$ (Huneeus et al., 2011) with large temporal and spatial variations. Monthly mean dust concentrations measured at Barbados (Prospero and Lamb, 2003) vary between $1-50 \mu \mathrm{g} \mathrm{m}^{-3}$ and might be representative for transatlantic transport of Saharan dust (Engelstaedter et al., 2006). The total suspended particle mass on Cape Verde for dust periods measured during SAMUM ranged between $250-410 \mu \mathrm{g} \mathrm{m}^{-3}$ (Kandler et al., 2011). In central Europe, dust free air masses from the North Atlantic and air containing Saharan dust alternate. Seifert et al. (2010) identify dust concentrations $>2 \mu \mathrm{g} \mathrm{m}^{-3}$ as dust episodes and present a moderate dust outbreak with dust peak concentrations of $160 \mu \mathrm{g} \mathrm{m}^{-3}$ at $4000 \mathrm{~m}$ measured at Leipzig. The vast majority of mineral dust particles transported through the atmosphere have sizes from 0.5 to $75 \mu \mathrm{m}$, with larger particles getting rarer with increasing distance from the source because of gravitational settling during atmospheric transport (Maring et al., 2003). As rule of thumb, sedimentation speeds are $v \approx 1 \mathrm{~m} \mathrm{~h}^{-1} \times(r / \mu \mathrm{m})^{2}$ for particles with effective radius $r$, resulting in roughly $1.5 \mathrm{~km}$ sedimentation per hour of particles with $75 \mu \mathrm{m}$ diameter. The Hoggar dust sample includes particles with diameters up to $32 \mu \mathrm{m}$ and its size distribution can be fitted with a tri-modal normal distribution with peaks at $35 \mathrm{~nm}, 340 \mathrm{~nm}$ and $2100 \mathrm{~nm}$. Particles with diameters smaller than $1 \mu \mathrm{m}\left(v<1 \mathrm{~m} \mathrm{~h}^{-1}\right)$ contribute about $6 \%$ to the surface area, and particles smaller than $10 \mu \mathrm{m}$ $\left(v<100 \mathrm{~m} \mathrm{~h}^{-1}\right)$ about $50 \%$. This is somewhat coarser but still comparable with dust aerosol surface area size distributions from the Canary Islands and Puerto Rico, in which particles smaller than $1 \mu \mathrm{m}$ are responsible for half, and particles smaller than $10 \mu \mathrm{m}$ for almost the entire dust surface area (Maring et al., 2003). The $0.005 \mathrm{wt} \%$ suspension of the 
Hoggar sample, which contained $1.25 \times 10^{-4} \mathrm{mg}$ of mineral dust froze in the temperature range $252-257 \mathrm{~K}$. Dilution by a factor of 10 caused freezing mostly below $252 \mathrm{~K}$, which is indistinguishable from freezing of the pure water reference. We therefore assume that in the $0.005 \mathrm{wt} \%$ suspension on average only 1-10 particles are responsible for freezing above $252 \mathrm{~K}$. This concentration of best IN per dust mass (1-10 particles/1.25 $\times 10^{-4} \mathrm{mg}$ ) can now be transformed to IN concentrations per air volume assuming typical values of dust loadings. Dividing the mass of dust in the $0.005 \mathrm{wt} \%$ suspension of the Hoggar sample by the mass concentration of dust in the air volume yields the volume of air, throughout which the mass of dust in the bulk sample would have been spread (i.e. $3.0 \times 10^{-4} \mathrm{~m}^{3}$ for an upper limit of $410 \mu \mathrm{g} \mathrm{m}^{-3}$ and $6.3 \times 10^{-2} \mathrm{~m}^{3}$ for $2 \mu \mathrm{g} \mathrm{m}^{-3}$ dust per air volume). This yields number densities in the atmosphere of best IN that are active above $252 \mathrm{~K}$ of $0.01-0.11^{-1}$ for low concentration dust events $\left(2 \mu \mathrm{g} \mathrm{m}^{-3}\right)$ and of $3-30 \mathrm{l}^{-1}$ for high concentration dust events $\left(410 \mu \mathrm{g} \mathrm{m}^{-3}\right)$. DeMott et al. (2010) presented data for IN number densities from different campaigns ranging from $0.1-101^{-1}$ for temperatures between $250 \mathrm{~K}$ and $265 \mathrm{~K}$. The best IN in the Hoggar sample are thus frequent enough to account for ambient IN number densities at least during dust events.

As we showed previously (Hoyle et al., 2011), assuming an IN layer thickness of $2 \mathrm{~km}$ for a IN number density of $0.11^{-1}$, atmospheric dehydration effect can be significant. This would suggest that already the few best IN have an impact on water vapour or cloud formation; therefore they should be taken into account. A major effect could result from higher IN number densities, e.g. $1001^{-1}$, which could lead to a complete dehydration of the column.

\section{Summary and conclusions}

We performed DSC emulsion and bulk freezing experiments to investigate immersion mode ice nucleation of the clay minerals kaolinite, montmorillonite, and illite from different sources, and of a natural sample from the Sahara region (Hoggar Mountains). All studied samples showed heterogeneous freezing, but there were considerable variations in the freezing onsets and the frozen fraction depending on clay mineral type, source region and pre-treatment performed by the supplier. In combination, emulsion and bulk freezing experiments on a single type of clay mineral reveal a very broad temperature range for ice nucleation from well over $260 \mathrm{~K}$ down to the onset of homogeneous ice nucleation. Such a broad freezing range can hardly be reconciled with the assumption of classical nucleation theory (CNT) that ice nucleation can be described as occurring stochastically on a homogeneous surface with uniform freezing probability. We therefore hypothesize that freezing is initiated on active sites and discriminate between standard, special and best sites: standard sites are present in all types of a clay mineral, while special sites occur in addition to standard sites, but only in certain types of clay minerals, and are active at higher temperatures. Best sites are very rare $\left(0.01-1 \mathrm{~cm}^{-2}\right)$, may differ greatly from sample to sample of the same type of mineral dust, and possibly originate from random defects. Ice nucleation on best sites is accessible by bulk DSC experiments, whereas emulsion experiments are needed to investigate standard and special sites.

The kaolinites show narrow standard peaks with onsets $239 \mathrm{~K}<T_{\text {on }}^{\text {std }}<242 \mathrm{~K}$ and best sites with averaged median freezing temperatures $T_{\text {med }}^{\text {best }} \approx 257 \mathrm{~K}$. Only the kaolinite from Sigma Aldrich (K-SA) featured a special peak with freezing onset $T_{\mathrm{on}}^{\text {spcl }} \approx 248 \mathrm{~K}$. The illites showed broad standard peaks with $244 \mathrm{~K}<T_{\text {on }}^{\text {std }}<246 \mathrm{~K}$ and best sites with $T_{\text {med }}^{\text {best }} \approx$ $262 \mathrm{~K}$. Montmorillonites had standard peaks with onsets $238 \mathrm{~K}<T_{\text {on }}^{\text {std }}<240 \mathrm{~K}$ and best sites with $T_{\text {med }}^{\text {best }} \approx 257 \mathrm{~K}$. M SWy-2, M K-10, and M KSF featured special peaks with onsets $T_{\mathrm{on}}^{\text {spcl }} \approx 247 \mathrm{~K}, 240 \mathrm{~K}$, and $242 \mathrm{~K}$, respectively. M K-10 and M KSF both from Sigma Aldrich had less intense standard peaks compared to the ones from the Clay Mineral Society suggesting that a part of the standard sites are lost by the acid treatment. The acid treatment had however, no evident effect on best sites.

Our investigations demonstrate that immersion freezing temperatures of clay minerals strongly depend on the amount of clay mineral present per droplet and the exact type (location of collection and pre-treatment) of the clay mineral. Results obtained by different scientific investigators using different setups can be reconciled when the clay type is the same and the dust amount in the investigated liquid volumes is comparable. Our bulk measurements, which are just sensitive to the best IN, clearly show that the high heterogeneous freezing temperatures reported in the older studies by Pitter and Pruppacher (1973) and Hoffer (1961) can be reached, but should not be mistaken to be characteristic for the freezing efficiency of the average dust particle.

The natural sample collected in the Sahara (Hoggar mountains) showed a broad freezing peak, with onsets $247 \mathrm{~K}<T_{\text {on }}^{\text {std }}<248 \mathrm{~K}$ and best sites with an averaged median freezing temperature $T_{\text {med }}^{\text {best }} \approx 261 \mathrm{~K}$. These freezing characteristics are very similar to the ones of the illites, which is in agreement with the supposed mineral composition of the Hoggar dust sample with a large share of illite. A comparison of the concentration of best IN in the Hoggar sample to observed Saharan dust concentrations over Cape Verde suggests that these IN should be frequent enough to account for ambient IN number densities, and that they could be active at temperatures between $250 \mathrm{~K}$ and $260 \mathrm{~K}$ during dust events.

More mineral dust samples from different deserts and different locations in desert areas have to be sampled to enlarge the picture of IN efficiency of mineral dusts and to validate the suitability of clay minerals as surrogates for natural dust samples. 
Acknowledgements. Valeria Pinti is funded by NCCR Climate. We thank Felix Lüönd, Luis Ladino Moreno, André Welti and Olaf Stetzer for their contribution and help for the size distribution measurements of the samples. We thank Felix Lüönd, André Welti and Zamin Kanji for their valuable contributions during discussions. We thank Eszter Barthazy Meier for the size distribution of the Hoggar dust sample, used for Fig. 2. We thank Lothar Schütz for providing the Hoggar dust sample and Wilfried Winkler for hosting us in his laboratory and for allowing us to sieve the Hoggar dust sample. We thank Maike Peter whose "Matura Arbeit" provided some of the bulk measurements of montmorillonite used in Fig. 10. We thank Annette Röthlisberger from the Institute for Geotechnical Engineering at ETH Zürich for BET measurements of the Hoggar dust sample.

Edited by: M. Petters

\section{References}

Abend, S. and Lagaly, G.: Sol-gel transitions of sodium montmorillonite dispersions, Appl. Clay Sci., 16, 201-227, 2000.

Ajjou, A. N., Harouna, D., Detellier, C., and Alper, H.: Cationexchanged montmorillonite catalyzed hydration of styrene derivatives, J. Mol. Catal. A, 126, 55-60, 1997.

Ansmann, A., Tesche, M,. Althausen, D., Mueller, D., Seifert, P., Freudenthaler, V., Heese, B., Wiegner, M., Pisani, G., Knippertz, P., and Dubovik, O.: Influence of Saharan dust on cloud glaciation in southern Morocco during the Saharan Mineral Dust Experiment., J. Geophys. Res., 113, D04210, doi:10.1029/2007JD008785, 2008.

Ansmann, A., Baars, H., Tesche, M., Mueller, D., Althausen, D., Engelmann, R., Pauliquevis, T., and Artaxo, P.: Dust and smoke transport from Africa to South America: Lidar profiling over Cape Verde and the Amazon rainforest, Geophys. Res. Lett., 36, L11802, doi:10.1029/2009GL037923, 2009.

Archuleta, C. M., DeMott, P. J., and Kreidenweis, S. M.: Ice nucleation by surrogates for atmospheric mineral dust and mineral dust/sulfate particles at cirrus temperatures, Atmos. Chem. Phys., 5, 2617-2634, doi:10.5194/acp-5-2617-2005, 2005.

Avila, A., Queralt-Mitjans, I., and Alarcon, M.: Mineralogical composition of African dust delivered by red rains over the northeastern Spain, J. Geophys. Res, 102, 21977-21996, 1997.

Blanco, A., Dee Tomasi, F., Filippo, E., Manno, D., Perrone, M. R., Serra, A., Tafuro, A. M., and Tepore, A.: Characterization of African dust over southern Italy, Atmos. Chem. Phys., 3, 21472159, doi:10.5194/acp-3-2147-2003, 2003.

Broadley, S. L., Murray, B. J., Herbert, R. J., Atkinson, J. D., Dobbie, S., Malkin, T. L., Condliffe, E., and Neve, L.: Immersion mode heterogeneous ice nucleation by an illite rich powder representative of atmospheric mineral dust, Atmos. Chem. Phys., 12, 287-307, doi:10.5194/acp-12-287-2012, 2012.

Carroll, D.: Ion exchange in clays and other minerals, Geol. Soc. Am. Bull., 70, 749-780, 1959.

Chudnovsky, A., Ben-Dor, E., Kostinski A. B., and Koren, I.: Mineral content analysis of atmospheric dust using hyperspectral information from space, Geophys. Res. Lett., 36, L15811, doi:10.1029/2009GL037922, 2009.

Conen, F., Morris, C. E., Leifeld, J., Yakutin, M. V., and Alewell, C.: Biological residues define the ice nucleation properties of soil dust, Atmos. Chem. Phys., 11, 9643-9648, doi:10.5194/acp-119643-2011, 2011.

Croteau, T., Bertram, A. K., and Patey, G. N.: Adsorption and structure of water on kaolinite surfaces: Possible insight into ice nucleation from Grand Canonical Monte Carlo Calculations, J. Phys. Chem. A, 112, 10708-10712, 2008.

Cziczo, D. J., Stetzer, O., Worringen, A., Ebert, M., Weinbruch, S., Kamphus, M., Gallavardin, S. J., Curtius, J., Borrmann, S., Froyd, K. D., Mertes, S., Möhler, O., and Lohmann, U.: Inadvertent climate modification due to anthropogenic lead, Nat. Geosci., 2, 333-336, doi:101038/NGEO499, 2009.

DeMott, P. J., Rogers, D. C., and Kreidenweis, S. M.: The susceptibility of ice formation in upper tropospheric clouds to insoluble aerosol components, J. Geophys. Res.-Atmos., 102, 1957519584, doi:10.1029/97JD01138, 1997.

DeMott, P. J., Sassen, K., Poellot, M. R., Baumgardner, D., Rogers, D. C., Brooks, S. D., Prenni, A. J., and Kreidenweis, S. M.: African dust aerosols as atmospheric ice nuclei, Geophys. Res. Lett., 30, 1732, doi:10.1029/2003GL017410, 2003a.

DeMott, P. J., Cziczo, D. M, Prenni, A. J., Murphy, D. M., Kreidenweis, S. M., Thomson, D. S., Borys, R., and Rogers, D. C.: Measurements of the concentration and composition of nuclei for cirrus formation, P. Natl. Acad. Sci. USA, 100, 14655-14660, doi:10.1073/pnas.2532677100, 2003b.

DeMott, P. J., Prenni, A. J., Liu, X., Kreidenweis, S. M., Petters, M. D., Twohy, C. H., Richardson, M. S., Eidhammer, T., and Rogers, D. C.: Predicting global atmospheric ice nuclei distributions and their impacts on climate, P. Natl. Acad. Sci. USA, 107, 1121711222, 2010.

Eastwood, M. L., Cremel, S., Gehrke, C., Girard, E., and Bertram, A. K.: Ice nucleation on mineral dust particles: Onset conditions, nucleation rates and contact angles, J. Geophys. Res., 113, D22203, doi:10.1029/2008JD010639, 2008.

Engelstaedter, S., Tegen, I., and Washington, R.: North African dust emissions and transport, Earth-Sci. Rev., 79, 73-100, 2006.

Ganor, E.: The composition of clay minerals transported to Israel as indicators of Saharan dust emission, Atmos. Environ., 25A, 2657-2664, 1991.

Glaccum, R. A. and Prospero, J. M.: Saharan aerosols over the tropical North Atlantic - Mineralogy, Mar. Geol., 37, 295-321, doi:10.1016/0025-3227(80)90107-3, 1980.

Gregg, S. L. and Sing, K. S. W.: Adsorption surface area and porosity, Academic Press, London, UK, 1982.

Haywood, J., Francis, P., Osborne, S., Glew, M., Loeb, N., Highwood, E., Tanré, D., Myhre, G., Formenti, P., and Hirst, E.: Radiative properties and direct radiative effect of Saharan dust measured by the C-130 aircraft during SHADE: 1 . Solar spectrum, J. Geophy. Res., 108, 8577, doi:10.1029/2002JD002687, 2003.

Hoffer, T. E.: A laboratory investigation of droplet freezing, J. Meteorol., 18, 766-778, 1961.

Hoose, C., Kristjánsson, J. E., and Burrows, S. M.: How important is biological ice nucleation in clouds on a global scale?, Environ. Res. Lett., 5, 024009, doi:10.1088/1748-9326/5/2/024009, 2010.

Hoyle, C. R., Pinti, V., Welti, A., Zobrist, B., Marcolli, C., Luo, B., Höskuldsson, Á., Mattsson, H. B., Stetzer, O., Thorsteinsson, T., Larsen, G., and Peter, T.: Ice nucleation properties of volcanic ash from Eyjafjallajökull, Atmos. Chem. Phys., 11, 9911-9926, doi:10.5194/acp-11-9911-2011, 2011. 
Huneeus, N., Schulz, M., Balkanski, Y., Griesfeller, J., Prospero, J., Kinne, S., Bauer, S., Boucher, O., Chin, M., Dentener, F., Diehl, T., Easter, R., Fillmore, D., Ghan, S., Ginoux, P., Grini, A., Horowitz, L., Koch, D., Krol, M. C., Landing, W., Liu, X., Mahowald, N., Miller, R., Morcrette, J.-J., Myhre, G., Penner, J., Perlwitz, J., Stier, P., Takemura, T., and Zender, C. S.: Global dust model intercomparison in AeroCom phase I, Atmos. Chem. Phys., 11, 7781-7816, doi:10.5194/acp-11-7781-2011, 2011.

Intergovernmental Panel on Climate Change (IPCC): Climate Change 2007: The Physical Science Basis, Cambridge University Press, UK, 2007.

Jiang, T. M., Hirasaki, G. J., and Miller, C. A.: Characterization of Kaolinite $\zeta$ Potential for Interpretation of Wettability Alteration in Diluted Bitumen Emulsion Separation, Energy Fuels, 24, 2350-2360, 2010.

Kamphus, M., Ettner-Mahl, M., Klimach, T., Drewnick, F., Keller, L., Cziczo, D. J., Mertes, S., Borrmann, S., and Curtius, J.: Chemical composition of ambient aerosol, ice residues and cloud droplet residues in mixed-phase clouds: single particle analysis during the Cloud and Aerosol Characterization Experiment (CLACE 6), Atmos. Chem. Phys., 10, 8077-8095, doi:10.5194/acp-10-8077-2010, 2010

Kandler, K., Schuetz, L., Jaeckel S., Lieke, K., Emmel, C., MuellerEbert, D., Ebert, M., Scheuvens, D., Schladitz, A., Segvic, B., Wiedensohler, A., and Weinbruch, S.: Ground-based off-line aerosol measurements at Praia, Cape Verde, during the Saharan Mineral Dust Experiment: microphysical properties and mineralogy, Tellus, 63B, 459-474, 2011.

Kanji, Z. A. and Abbatt, J. P. D.: Ice Nucleation onto Arizona Test Dust at cirrus temperatures: Effect of temperature and aerosol size on onset relative humidity, J. Phys. Chem. A., 114, 935-941, 2010.

Kanji, Z. A., Florea, O., and Abbatt, J. P. D.: Ice formation via deposition nucleation on mineral dust and organics: dependence of onset relative humidity on total particulate surface areas, Environ. Res. Lett., 3, 025004, doi:10.1088/1748-9326/3/2/025004, 2008.

Kim, Y. S., Iwasaka, Y., Shi, G.-Y., Nagatani, T., Shibata, T., Trochkine, D., Matsuki, A., Yamada, M., Chen, B., Zhang, D., Nagatani, M., and Nakata, H.: Dust particles in the free atmosphere over desert areas on the Asian continent: Measurements from summer 2001 to summer 2002 with balloon-borne optical particle counter and lidar, Dunhuang, China, J. Geophys. Res., 109, D19S26, doi:10.1029/2002JD003269, 2004.

Knopf, D. A. and Koop, T.: Heterogeneous nucleation of ice on surrogates of mineral dust, J. Geophys. Res., 111, D12201, doi:10.1029/2005JD006894, 2006.

Koehler, K. A., Kreidenweis, S. M., DeMott, P. J., Petters, M. D., Prenni, A. J., and Möhler, O.: Laboratory investigations of the impact of mineral dust aerosol on cold cloud formation, Atmos. Chem. Phys., 10, 11955-11968, doi:10.5194/acp10-11955-2010, 2010.

Kretzschmar, R., Holthoff, H., and Sticher, H.: Influence of $\mathrm{pH}$ and Humic Acid on Coagulation Kinetics of Kaolinite: A Dynamic Light Scattering Study, J. Colloid Interface Sci., 202, 95-103, 1998.

Kulkarni, G. and Dobbie, S.: Ice nucleation properties of mineral dust particles: determination of onset $\mathrm{RH}_{i}$, IN active fraction, nucleation time-lag, and the effect of active sites on contact angles,
Atmos. Chem. Phys., 10, 95-105, doi:10.5194/acp-10-95-2010, 2010.

Kumai, M.: Snow crystals and the identification of the nuclei in the Northern United States of America, J. Meteorol., 18, 139-150, 1961.

Kumai M. and Francis, K. E.: Nuclei in snow and ice crystals on the Greenland Ice Cap under natural and artificially stimulated conditions, J. Atmos. Sci., 19, 474-481, 1962.

Kumar, P., Sokolik, I. N., and Nenes, A.: Measurements of cloud condensation nuclei activity and droplet activation kinetics of fresh unprocessed regional dust samples and minerals, Atmos. Chem. Phys., 11, 3527-3541, doi:10.5194/acp-11-3527-2011, 2011.

Lancaster, N.: Geomorphology of Desert Dunes, London, New York, Routledge, 1995.

Laurent, B., Tegen, I., Heinold, B., Schepanski, K., Weinzierl, B., and Esselborn, M.: A model study of Saharan dust emissions and distributions during the SAMUM1 campaign, J. Geophys. Res., 115, D21210, doi:10.1029/2009JD012995, 2010.

Levin, Z., Ganor, E., and Gladstein, V.: The effects of desert particles coated with sulfate on rain formation in the eastern Mediterranean, J. Appl. Meteor., 35, 1511-1523, 1996.

Lüönd, F., Stetzer, O., Welti, A., and Lohmann, U.: Experimental study on the ice nucleation ability of size-selected kaolinite particles in the immersion mode, J. Geophys. Res., 115, D14201, doi:10.1029/2009JD012959, 2010.

Mahowald, N. M. and Kiehl, L. M.: Mineral aerosol and cloud interactions, Geophys. Res. Lett., 30, 1475, doi:10.1029/2002GL016762, 2003.

Marcolli, C., Gedamke, S., Peter, T., and Zobrist, B.: Efficiency of immersion mode ice nucleation on surrogates of mineral dust, Atmos. Chem. Phys., 7, 5081-5091, doi:10.5194/acp-7-50812007, 2007.

Maring, H., Savoie, D. L., Izaguirre, M. A., Custals, L., and Reid, J. S.: Mineral dust aerosol size distribution change during atmospheric transport, J. Geophys. Res., 108, 8592, doi:10.1029/2002JD002536, 2003.

Möhler, O., Field, P. R., Connolly, P., Benz, S., Saathoff, H., Schnaiter, M., Wagner, R., Cotton, R., Krämer, M., Mangold, A., and Heymsfield, A. J.: Efficiency of the deposition mode ice nucleation on mineral dust particles, Atmos. Chem. Phys., 6, 30073021, doi:10.5194/acp-6-3007-2006, 2006.

Moreno, T., Querol, X., Castillo, S., Alastuey, A., Cuevas, E., Herrmann, L., Mounkaila, M., Elvira, J., and Gibbons, W.: Geochemical variations in aeolian mineral particles from the Sahara-Sahel dust corridor, Chemosphere, 65, 261-270, doi:10.1016/j.chemosphere.2006.02.052, 2006.

Murray, B. J., Wilson, T. W., Broadley, S. L., and Wills, R. H.: Heterogeneous freezing of water droplets containing kaolinite and montmorillonite particles, Atmos. Chem. Phys. Discuss., 10, 9695-9729, doi:10.5194/acpd-10-9695-2010, 2010.

Murray, B. J., Broadley, S. L., Wilson, T. W., Atkinson, J. D., and Wills, R. H.: Heterogeneous freezing of water droplets containing kaolinite particles, Atmos. Chem. Phys., 11, 4191-4207, doi:10.5194/acp-11-4191-2011, 2011.

Niedermeier, D., Hartmann, S., Clauss, T., Wex, H., Kiselev, A., Sullivan, R. C., DeMott, P. J., Petters, M. D., Reitz, P., Schneider, J., Mikhailov, E., Sierau, B., Stetzer, O., Reimann, B., Bundke, U., Shaw, R. A., Buchholz, A., Mentel, T. F., and Stratmann, F.: 
Experimental study of the role of physicochemical surface processing on the IN ability of mineral dust particles, Atmos. Chem. Phys., 11, 11131-11144, doi:10.5194/acp-11-11131-2011, 2011.

Nieto, F., Mellini, M., and Abad, I.: The role of $\mathrm{H}_{3} \mathrm{O}^{+}$in the crystal structure of illite, Clay. Clay Miner., 58, 238-246, 2010.

O'Hara, S. L., Clarke, M. L., and Elatrash, M. S.: Field measurements of desert dust deposition in Libya, Atmos. Environ., 40, 3881-3897, 2006.

Pitter, R. L. and Pruppacher, H. R.: A wind tunnel investigation of freezing of small water drops falling at terminal velocity in air, Q. J. Roy. Meteor. Soc., 99, 540-550, doi:10.1002/qj.49709942111, 1973.

Prospero, J. M. and Lamb, P. J.: African droughts and dust transport to the Caribbean: climate change implications, Science, 302, 1024-1027, 2003.

Pruppacher, H. R. and Klett, J. D.: Microphysics of clouds and precipitation, Kluwer, Dordrecht, 191-209, 309-355, 1997.

Rosenfeld, D., Rudich, Y., and Lahav, R.: Desert dust suppressing precipitation: A possible desertification feedback loop, P. Natl. Acad. Sci. USA, 98, 5975-5980, 2001.

Rudich, Y., Khersonsky, O., and Rosenfeld, D.: Treating clouds with a grain of salt, Geophys. Res. Lett., 29, 2060, doi:10.1029/2002GL016055, 2002.

Rudich, Y., Sagi, A., and Rosenfeld, D.: Influence of the Kuwait oil fire plume (1991) on the microphysical development of clouds, J. Geophys. Res., 108, 4478, doi:10.1029/2003JD003472, 2003.

Sakai, T., Nagai, T., Nakazato, M., and Matsumura, T.: Raman lidar measurement of water vapor and ice clouds associated with Asian dust layer over Tsukuba, Japan, Geophys. Res. Lett., 31, L06128, doi:10.1029/2003GL019332, 2004.

Salam, A., Lohmann, U., Crenna, B., Lesins, G., Klages, P., Rogers, D., Irani, R., MacGillivray, A., and Coffin, M.: Ice nucleation studies of mineral dust particles with a new continuous flow diffusion chamber, Aerosol. Sci. Technol., 40, 134-143, 2006.

Sassen, K.: Indirect climate forcing over the western US from Asian dust storms, Geophys. Res. Lett., 29, 1465, doi:10.1029/2001GL014051, 2002.

Sassen, K., DeMott, P. J., Prospero, J. M., and Poellot, M. R.: Saharan dust storms and indirect aerosol effects on clouds: CRYSTAL-FACE results, Geophys. Res. Lett., 30, 1633, doi:10.1029/2003GL017371, 2003.

Schulz, M., Balkanski, Y. J., Guelle, W., and Dulac, F.: Role of aerosol size distribution and source location in a threedimensional simulation of a Saharan dust episode tested against satellite-derived optical thickness, J. Geophys. Res., 103, 1057910592, doi:10.1029/97JD02779, 1998.

Seifert, P., Ansmann, A., Mattis, I., Wandinger, U., Tesche, M., Engelmann, R., Müller, D., Pérez, C., and Haustein, K.: Saharan dust and heterogeneous ice formation: Eleven years of cloud observations at a central European EARLINET site, J. Geophys. Res., 115, D20201, doi:10.1029/2009JD013222, 2010.

Suarez Barrios, M., de Santiago Buey, C., Garcia Romero, E., and Martin Pozas, J. M.: Textural and structural modifications of saponite from Cerro del Aguila by acid treatment, Clay Miner., 36, 483-488, doi:10.1180/0009855013640003, 2001.

Szyrmer, W. and Zawadzki, I.: Biogenic and anthropogenic sources of ice-forming nuclei: A review, B. Am. Meteorol. Soc., 78, 209228, 1997.
Teipel, U., Winter, H., Cäsar, J., and Gromov, A.: Characterization of test dust for product qualification, Bulk Solids \& Powder Science \& Technology, 3, 155-161, 2008.

Tombácz, E. and Szekeres, M.: Surface charge heterogeneity of kaolinite in aqueous suspension in comparison with montmorillonite, Appl. Clay Sci., 34, 105-124, 2006.

Tombácz, E., Libor, Z., Illés, E., Majzik, A., and Klumpp, E.: The role of reactive surface sites and complexation by humic acids in the interaction of clay mineral and iron oxide particles, Org. Geochem., 35, 257-267, 2004.

Toon, O. B.: African dust in Florida clouds, Nature, 424, 623-624, 2003.

Twohy, C. H. and Poellot, M. R.: Chemical characteristics of ice residual nuclei in anvil cirrus clouds: evidence for homogeneous and heterogeneous ice formation, Atmos. Chem. Phys., 5, 22892297, doi:10.5194/acp-5-2289-2005, 2005.

Vali, G.: Repeatability and randomness in heterogeneous freezing nucleation, Atmos. Chem. Phys., 8, 5017-5031, doi:10.5194/acp-8-5017-2008, 2008.

Vali, G. and Stansbury, E. J.: Time dependent characteristics of the heterogeneous nucleation of ice, Can. J. Phys., 44, 477-502, 1966.

Viani, A., Gualtieri, A. F., and Artioli, G.: The nature of disorder in montmorillonite by simulation of X-ray powder patterns, Am. Mineral., 87, 966-975, 2002.

Welti, A., Lüönd, F., Stetzer, O., and Lohmann, U.: Influence of particle size on the ice nucleating ability of mineral dusts, Atmos. Chem. Phys., 9, 6705-6715, doi:10.5194/acp-9-6705-2009, 2009.

Wheeler, M. J. and Bertram, A. K.: Deposition nucleation on mineral dust particles: a case against classical nucleation theory with the assumption of a single contact angle, Atmos. Chem. Phys., 12, 1189-1201, doi:10.5194/acp-12-1189-2012, 2012.

Wiacek, A. and Peter, T.: On the availability of uncoated mineral dust ice nuclei in cold cloud regions, Geophys. Res. Lett., 36, L17801, doi:10.1029/2009GL039429, 2009.

Wiacek, A., Peter, T., and Lohmann, U.: The potential influence of Asian and African mineral dust on ice, mixed-phase and liquid water clouds, Atmos. Chem. Phys., 10, 8649-8667, doi:10.5194/acp-10-8649-2010, 2010.

Yin, Y., Wurzler, S., Levin, Z., and Reisin, T. G.: Interactions of mineral dust particles and clouds: Effects on precipitation and cloud optical properties, J. Geophys. Res., 107, 4724, doi:10.1029/2001JD001544, 2002.

Zimmermann, F., Weinbruch, S., Schütz, L., Hofmann, H., Ebert, M., Kandler, K., and Worringen, A.: Ice nucleation properties of the most abundant mineral dust phases, J. Geophys. Res., 113, D23204, doi:10.1029/2008JD010655, 2008.

Zobrist, B., Marcolli, C., Koop, T., Luo, B. P., Murphy, D. M., Lohmann, U., Zardini, A. A., Krieger, U. K., Corti, T., Cziczo, D. J., Fueglistaler, S., Hudson, P. K., Thomson, D. S., and Peter, T.: Oxalic acid as a heterogeneous ice nucleus in the upper troposphere and its indirect aerosol effect, Atmos. Chem. Phys., 6, 3115-3129, doi:10.5194/acp-6-3115-2006, 2006.

Zobrist, B., Koop, T., Luo, B. P., Marcolli, C., and Peter, T.: Heterogeneous ice nucleation rate coefficient of water droplets coated by a nonadecanol monolayer, J. Phys. Chem. C, 111, 2149-2155, 2007. 
Zobrist, B., Marcolli, C., Pedernera, D. A., and Koop, T.: Do atmospheric aerosols form glasses?, Atmos. Chem. Phys., 8, 52215244, doi:10.5194/acp-8-5221-2008, 2008.
Zuberi, B., Bertram, A. K., Cassa, C. A., Molina, L. T., and Molina, M. J.: Heterogeneous nucleation of ice in $\left(\mathrm{NH}_{4}\right)_{2} \mathrm{SO}_{4}-\mathrm{H}_{2} \mathrm{O}$ particles with mineral dust immersions, Geophys. Res. Lett., 29, 1504, doi:10.1029/2001GL014289, 2002. 